Article

\title{
Sr-Nd Isotopic Composition of Pyroxenes as a Provenance Indicator of a Double-Volcanic Source in Sands of the Ofanto River (Southern Italy)
}

\author{
Paola Donato ${ }^{1, *(\mathbb{D})}$, Rosanna De Rosa ${ }^{1}$, Mariano Tenuta ${ }^{2,3}$, Raffaella Silvia Iovine ${ }^{4}$, Federica Totaro ${ }^{5}$ \\ and Massimo D'Antonio ${ }^{5}$ (D)
}

1 Department of Biology, Ecology and Earth Sciences, University of Calabria, Ponte P. Bucci, 15B, 87036 Rende, Italy; rosanna.derosa@unical.it

2 Department of Innovation \& Information Engineering, Guglielmo Marconi University, 00193 Roma, Italy; mariano.tenuta@gmail.com

3 PoliS-Lombardia, Regional Institute for Lombardia Policy Support, Via Taramelli, 12, 20124 Milano, Italy

4 Istituto Nazionale di Geofisica e Vulcanologia Sezione di Napoli, Osservatorio Vesuviano, Via Diocleziano, 328, 80124 Naples, Italy; raffaella.iovine@ingv.it

5 Department of Earth, Environmental and Resources Sciences, University Federico II, Via Vicinale Cupa Cintia 21, 80126 Naples, Italy; federica.totaro@unina.it (F.T.); masdanto@unina.it (M.D.)

* Correspondence: paola.donato@unical.it

check for

updates

Citation: Donato, P.; De Rosa, R.;

Tenuta, M.; Iovine, R.S.; Totaro, F.;

D'Antonio, M. Sr-Nd Isotopic

Composition of Pyroxenes as a

Provenance Indicator of a

Double-Volcanic Source in Sands of the Ofanto River (Southern Italy).

Minerals 2022, 12, 232. https://

doi.org/10.3390/min12020232

Academic Editor: Ivan Vlastélic

Received: 14 December 2021

Accepted: 8 February 2022

Published: 11 February 2022

Publisher's Note: MDPI stays neutral with regard to jurisdictional claims in published maps and institutional affiliations.

Copyright: (c) 2022 by the authors Licensee MDPI, Basel, Switzerland. This article is an open access article distributed under the terms and conditions of the Creative Commons Attribution (CC BY) license (https:/ / creativecommons.org/licenses/by/ $4.0 /)$.

\begin{abstract}
The sands of the Ofanto River (Southern Italy) include a volcaniclastic component represented by clinopyroxene, melanite garnet, amphibole and subordinate volcanic lithics. In order to infer the provenance of this component, we have conducted a microanalytical and isotopic study on the volcanic minerals of the sands collected in three different sites along the Ofanto River: (1) upstream sector, where only sedimentary rocks are drained; (2) middle course, along a tributary draining only the Monte Vulture volcanic rocks, (3) the mouth of the Ofanto. Moreover, minerals of the beach sands of the Tyrrhenian Cilento coast were analyzed for comparison. The microanalytical study and the $\mathrm{Sr}-\mathrm{Nd}$ isotopic composition reveal the existence of two populations of pyroxenes characterized by distinct isotopic signatures and indicating a provenance from two different volcanic sources. One is confidently identifiable with Monte Vulture, and is evident in the minerals of the middle course and mouth sands. The pyroxenes of the upstream sector, isotopically similar to those of the Cilento coast, have a Campanian signature. The simultaneous occurrence of amphibole and garnet point to the explosive eruptions of Mount Vesuvius as the most probable sources of these minerals. The absence of Campanian pyroxenes at the mouth of the Ofanto River could be related to the occurrence of dams limiting the transport of solids along the river.
\end{abstract}

Keywords: Sr-Nd isotopic fingerprint; Southern Italy volcanoes; volcanic minerals; volcanic input in fluvial basin; fluvial transport; Ofanto Basin; Cilento Beach

\section{Introduction}

The Cenozoic magmatic rocks of Italy show extremely variable radiogenic and stable isotopic signatures (e.g., [1] and references therein). In particular, a decrease in ${ }^{87} \mathrm{Sr} /{ }^{86} \mathrm{Sr}$, $\delta^{18} \mathrm{O}, \delta^{13} \mathrm{C}$ and ${ }^{3} \mathrm{He} /{ }^{4} \mathrm{He}$ ratios and an increase in ${ }^{143} \mathrm{Nd} /{ }^{144} \mathrm{Nd}$ and ${ }^{206} \mathrm{~Pb} /{ }^{204} \mathrm{~Pb}$ from northwest to southeast is observed (e.g., [2,3] and references therein). However, despite this wide heterogeneity at the scale of the whole peninsula, each Italian magmatic province exhibits rather restricted and distinct isotopic signatures [1,3]. This allows the use of isotopic compositions as a tool to infer the provenance of volcanic material (glass, whole rock or minerals) in the Italian Peninsula and Mediterranean area, in tephrostratigraphic (e.g., [4-6]) and archaeometric studies of pottery made from volcanic rocks as raw material (e.g., [7]). 
In this work, we have used the isotopic ratios as the main tool to identify the sources of the volcanic minerals occurring in the sands of the Ofanto River (Southern Italy). In the central part of its course, the river and its tributaries drain through the volcanic rocks of Monte Vulture. However, the geographic position of the Ofanto Basin makes it an ideal collector of volcaniclastic sediment deriving from explosive eruptions of other Southern Italy volcanoes located outside the basin itself. Recent studies showed that a volcaniclastic fraction, mainly made up of clinopyroxene, and subordinately of amphibole, garnet and volcanic rock fragments, also occurs in the sands of the upstream portion of the Ofanto River, where no volcanic rocks outcrop [8]. In order to distinguish the different potential volcanic sources of the present river's sediments, we analyzed three sand samples, from the upstream portion, central sector and mouth of the Ofanto River, respectively; for each of the sampling points, the area occupied by different lithologies was calculated. Furthermore, a microanalysis of mineral phases coupled with the determination of ${ }^{143} \mathrm{Nd} /{ }^{144} \mathrm{Nd}$ and ${ }^{87} \mathrm{Sr} /{ }^{86} \mathrm{Sr}$ ratios was carried out to ascribe the volcaniclastic fraction to one or more of the several volcanic provinces of Central-Southern Italy. Finally, in order to have a comparison term, we carried out the same analyses on the same mineral species occurring in the sands of Cilento Beach (Campania, Southern Italy), where the geographic position strongly indicated their origin being from the Campanian volcanoes.

In areas with a high density of volcanoes, such as Southern Italy, the identification of the contribution from different volcanoes, not necessarily directly drained by the river, is of paramount importance in palaeo-geographic reconstructions, as well as in environmental studies. However, a traditional component analysis does not always distinguish between volcanic sources. The main aim of this work is to demonstrate how, combining petrography and microanalyses with isotopic analyses can help to identify the volcaniclastic contributions from different volcanic provinces to the sedimentation in river basins.

Detecting the variation of a volcanic contribution along the river's course can also provide useful information on the fluvial transport processes, particularly on the influence of anthropic water regulation structures such as dams on the sediment transport to the sea.

Finally, distinguishing the volcanic contribution of different eruptive sources in the river and beach sands can also contribute to reconstructing the dispersion of primary explosive volcanic products, not always well preserved in the continental areas.

\section{Geological Background}

\subsection{The Ofanto Basin}

The Ofanto River drainage basin covers an area of $2780 \mathrm{~km}^{2}$ in the Southern Apennines' northwestern sector (Figure 1a). The river springs are near the town of Nusco, in Campania. It flows in a W-E direction for the first $30 \mathrm{~km}$, then it borders the western flank of the Monte Vulture volcano, following a S-N direction for about $30 \mathrm{~km}$, and finally flows SW-NE until reaching its mouth near the town of Margherita di Savoia, along the Adriatic coast.

In the upstream zone, the river mainly drains the Apennine units (Figure 1b). They include the Sicilide complex, represented here by a chaotic complex made up of olistostromes, slides and huge olistoliths with different compositions and provenances set in a varicolored clayey matrix [9], as well as yellowish quartz arenites of the Numidian Flysch [10]. The Ofanto River also drains the mudstones, marls, microbreccias and quartz arenites of Lagonegro-Sannio-Molise units, minor limestones and dolomites of the CampaniaLucania units, and predominantly, Pliocene deposits formed by conglomerates interbedded with thin-laminated sandstones, siltstones and clay that represent the thrust-sheet-top basins $[10,11]$.

The other thrust-sheet-top basins (Castelvetere and San Bartolomeo formations) are poorly represented in the drainage basins, with sandstones, claystones and conglomerates cropping out only locally. In particular, the Castelvetere Formation is characterized by siliciclastic deposits, mostly disorganized, coarse-grained quartz-feldspathic sandstones and polygenic conglomerates consisting of igneous rocks and subordinate sedimentary and low-medium grade metamorphic rocks [13,14]. 


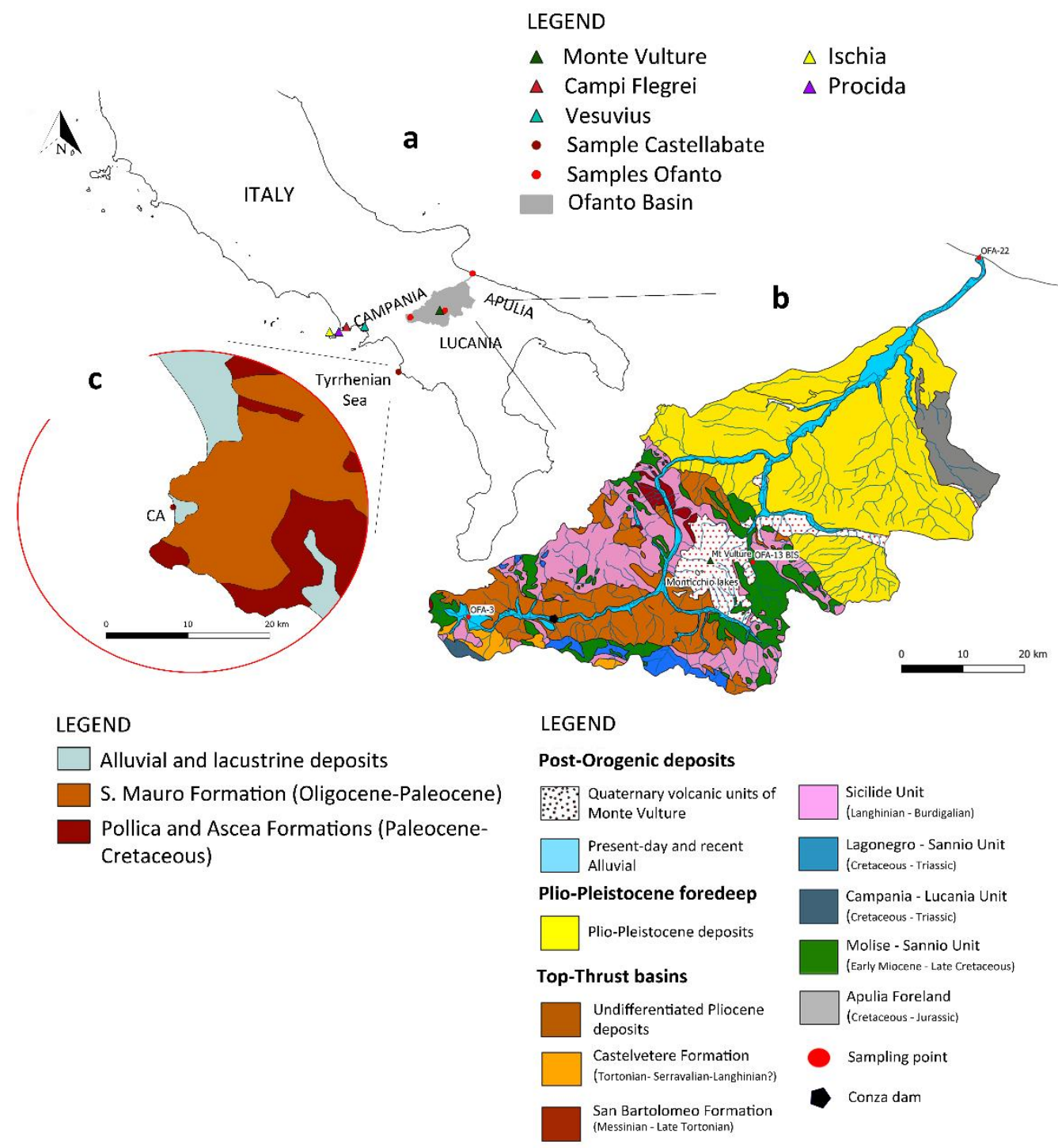

Figure 1. (a) Location of the Ofanto Basin and sampling points. The position of the main volcanoes of the area is also shown; (b) Geological map of the Ofanto Basin (modified after [10]). The position of the sampling points and the Conza dam is also shown; (c) Geological map of the area of Castellabate (modified after [12]).

Monte Vulture occupies most of the central sector of the Ofanto Basin. This composite volcano was active between $687 \pm 8 \mathrm{ka}$ and $141 \pm 11 \mathrm{ka}$ B.P. [15] and made up of a $700 \mathrm{~m}$ thick pyroclastic succession with some interbedded lava flows [16]. The Monte Vulture lavas and pyroclastics range from $\mathrm{SiO}_{2}$-undersaturated to strongly undersaturated [17-19] and contain abundant $\mathrm{Ca}$-rich, diopside to hedenbergite clinopyroxene, olivine, and amphibole, together with plagioclase, alkali feldspars, feldspathoids (mainly haüyne and leucite), melanitic garnet and rare melilite $[18,20,21]$.

Along the final segment of its course, the Ofanto River and its tributaries mainly drain Plio-Pleistocene deposits (yellow sand, conglomerates and bluish claystones) from the Bradanic foredeep and the Mesozoic limestones and calcarenites of Apulia Foreland [10].

The oldest deposits related to the river Ofanto are the Lioni Synthem (Middle-Upper Pleistocene), represented by fluvio-lacustrine sediments. Deposits of the Conza della Campania (Middle Pleistocene-Olocene) and Fosso dello Stroppito (Middle-Upper Pleistocene) Synthems form different orders of fluvial terraces related to the Ofanto River and its tributary, Fiumara Atella, respectively [22]. 
Aside from Monte Vulture, several other volcanoes generated widely dispersed ash in the Ofanto Basin, at least during the last $100 \mathrm{ka}$. In the maar lake sediments of Lago Grande di Monticchio, tephra layers from Somma-Vesuvius, Campi Flegrei, Ischia Island, Aeolian Islands, Alban Hills and Mount Etna were identified [23]. Two tephra layers were also recognized in the young fluvial terraces of the Ofanto Basin. The older, dated to $40.7 \pm 8.4 \mathrm{ka}$, was correlated with the Campi Flegrei Campanian Ignimbrite [16,24,25]; the younger $(25 \pm 5 \mathrm{ka},[16,24]$ was generically attributed to an eruption from either Somma-Vesuvius or Campi Flegrei.

\subsection{The Cilento Area}

On the Tyrrhenian coast of Southern Italy, the Cilento area is mainly made up of the socalled "Internidi" Oligo-Miocene terrigenous units, superimposed on the Lower CretaceousLower Miocene carbonatic rocks ([12,26] and cited references). The Internidi units consist of turbiditic limestone/silicate-claystone or clayey arenites in which three tectonic units can be distinguished: the North Calabrian units (Crete Nere and Saraceno Formations, [12,26-28], the "Sicilide-like" units and the Sicilide units s.s. Above the uppermost tectonic units, a Miocene syn-tectonic turbiditic unit, named the Cilento group, crops out [12,26]. In the area of Castellabate, the Cilento group is mainly represented by the San Mauro Formation, a turbiditic succession of clayey arenites and sand-grade limestone/silicate-claystone with conglomerate layers (Figure 1c). A volcaniclastic fraction occurs in the sandstone layers in the lowermost portion of the San Mauro formation, and is mainly represented by rhyolitic rock fragments and loose crystals of plagioclase and quartz [29,30]. The San Mauro Formation is drained, in the area of Castellabate, by the Testene stream.

The volcanoes of the Campanian province (Vesuvius, Campi Flegrei, Ischia, Procida) are all at a distance $<100 \mathrm{~km}$ from the area of Castellabate. A significant volcaniclastic fraction occurs in the sands of the beaches of Naples Bay; in particular, a component attributed to the activity of Vesuvius was found in the sector between Naples and Sorrento [31].

\section{Sampling}

The sediments along the Ofanto River were sampled in three different localities, from the upstream sector to the mouth (Figure 1a,b), chosen on the basis of the different lithologies drained by the river and the accumulation of dark-colored minerals in the sandy fraction. The bulk sediment from active sandy bars (Sample OFA-3b), from the riverbed (Sample OFA-13bis), or from the beach sand at the river mouth (OFA-22 and $22 \mathrm{~b}$ ) was picked up and sieved with a mesh of $11.2 \mathrm{~mm}$, in order to eliminate the coarse fraction. For each locality, the sub-basin feeding the sampling point was outlined, and the area covered by each lithology, obtained by the lithological map (1:500,000 scale) of the National Geoportal of the Environment Ministry (http:/ / www.pcn.minambiente.it/ mattm/servizio-di-scaricamento-wfs / (accessed on 15 December 2021)), was calculated. The used procedure and software are described in [8]. A further sample was collected from the beach sand of Castellabate, on the Tyrrhenian Cilento coast (Figure 1c).

\subsection{Sample OFA-3b}

The sampling site, OFA-3, is located in the upstream part of the Ofanto Basin. Sample OFA-3b was collected from an active sandy bar on the right bank of the river; locally dark minerals accumulate in the sand (Figure 2a). The coarse fraction in the river sediment mainly comprises carbonate and other sedimentary rocks. The main lithologies outcropping in the drainage sub-basin feeding this point are represented by claystones and marls of the Sicilide units, followed by the weathered limestone and marls of the Molise-Sannio unit. Calcareous-dolomitic deposits of the Campania-Lucania unit and sandstone, as well as conglomerates of undifferentiated Pliocene deposits are also drained. Moreover, a source of sediments is also represented by recent alluvial deposits in the Lioni basin, also containing a volcaniclastic fraction from Monte Vulture (Figure 2a). 
a

Sampling site OFA- 3

(Ofanto upstream)

coordinates:

$40^{\circ} 53^{\prime} 25^{\prime \prime} \mathrm{N}$

$15^{\circ} 9^{\prime} 26^{\prime \prime} \mathrm{E}$
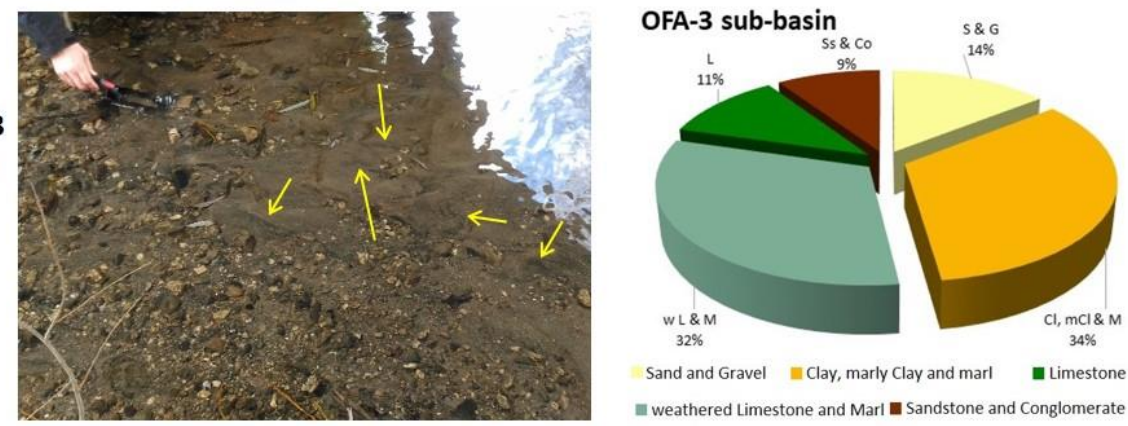

m weathered Limestone and Marl $\mathbf{m}$ Sandstone and Conglomerate

b

Sampling site OFA- 13

(Ofanto central sector)

coordinates:

$40^{\circ} 56^{\prime} 25^{\prime \prime} \mathrm{N}$

$15^{\circ} 42^{\prime} 43^{\prime \prime} \mathrm{E}$

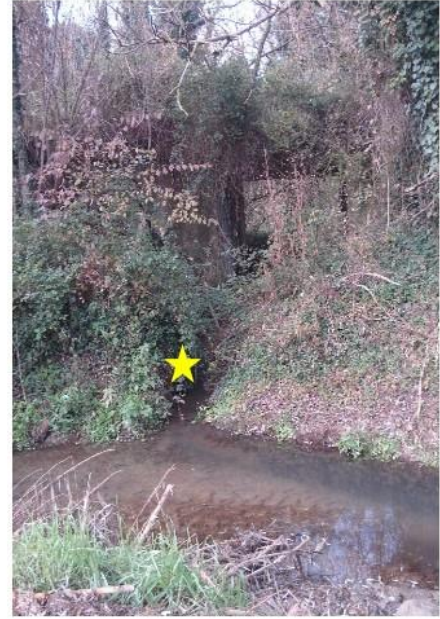

OFA-13bis sub-basin

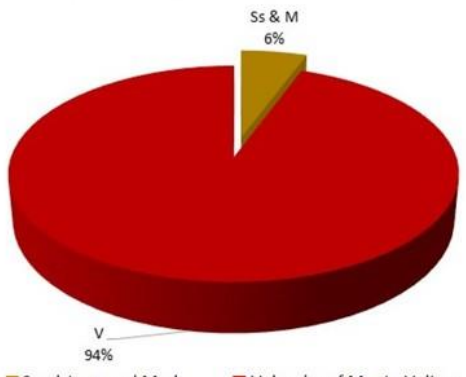

- Sandstone and Marl

C

Sampling site OFA- 22

(Ofanto mouth)

coordinates:

$41^{\circ} 21^{\prime} 34^{\prime \prime} \mathrm{N}$

$16^{\circ} 11^{\prime} 46^{\prime \prime} \mathrm{E}$

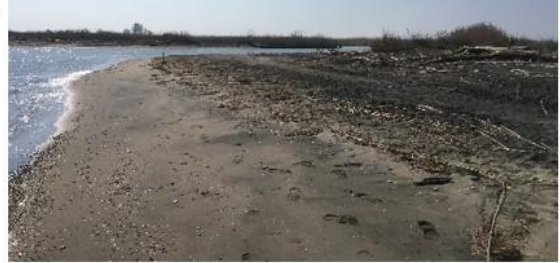

OFA-22 sub-basin

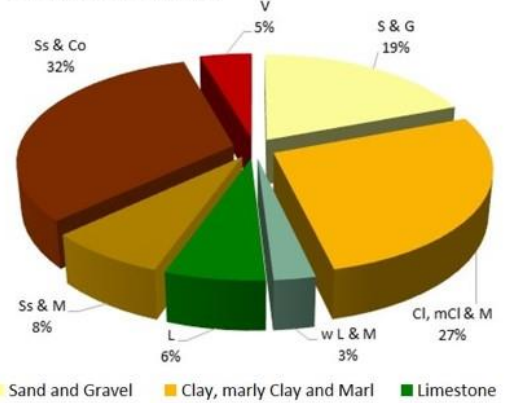

Sandstone and Marl Gandstone and Conglomerate

a Volcanics of Monte Vulture $\quad$ Weathered limestone and marl

\section{d}

Sampling site CA (Cilento beach) coordinates:

$40^{\circ} 14^{\prime} 44^{\prime \prime} \mathrm{N}$ $14^{\circ} 54^{\prime} 45^{\prime \prime} \mathrm{E}$

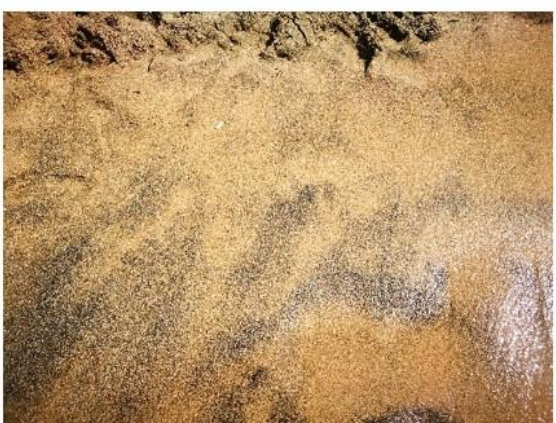

Figure 2. (a) Left: coordinates and picture of sampling site OFA-3. The yellow arrows indicate accumulation of dark minerals; right: percentages of the lithologies drained by the Ofanto River in the sub-basin feeding this sampling site (modified after [8]); (b) left: coordinates and picture of sampling site OFA-13bis. The yellow star indicates the site along the small tributary where the sample was picked up; right: percentages of the lithologies drained by the tributary in the sub-basin feeding 
this sampling site (modified after [8]); (c) left: coordinates and picture of the Ofanto mouth and the beach of Margherita di Savoia (sampling site OFA-22). Accumulations of dark minerals (sample 22b) are clearly visible on the beach. Right: percentages of the lithologies drained by the Ofanto River in the whole basin (modified after [8]); (d) coordinates and picture of sampling site CA on the beach of Castellabate (Cilento Tyrrhenian coast).

\subsection{Sample OFA-13bis}

Site OFA-13 is located in the intermediate portion of the Ofanto drainage basin, along Fiumara Arcidiaconata, a right tributary of the Ofanto River flowing on the eastern slope of the Monte Vulture volcano. The sediment is rather sandy, and dark minerals accumulate on the ripples' crest in the riverbed. The sample OFA-13bis was picked up from a small creek bed, a few meters upstream of its confluence with Fiumara Arcidiaconata (star in Figure $2 \mathrm{~b}$ ). The sub-basin feeding this point almost exclusively drains the volcanic rocks of Monte Vulture.

\subsection{Sample OFA-22 and $22 b$}

Sample OFA-22 represents a beach sand from the Ofanto mouth, on the Adriatic coast and near the town of Margherita di Savoia (Apulia). This area shows evidence of high erosion rates and retreatment of the mouth, as witnessed by the shape of the mouth, a simple channel without ramification, and the occurrence of well-developed soil very close to the beach. The beach is sandy and shows diffuse accumulations of dark-colored minerals (Figure 2c). A small trench dug on the beach revealed an alternation of light and dark levels. Two samples were collected here: OFA-22 is the bulk sediment, and was used for the component analyses; OFA-22b is an accumulation of dark minerals from which crystals were separated for microanalyses and isotopic analyses. The whole Ofanto drainage basin feeds this sampling point; the percentages of drained lithologies are shown in Figure 2c.

\subsection{Sample $C A$}

Aside from the samples from the Ofanto River, we also collected a sample (CA) from the Tyrrhenian coast of Cilento, near the town of Castellabate. The beach is sandy and mainly composed of carbonate grains. However, locally, it shows accumulations of dark minerals very similar to those of Margherita di Savoia (Figure 2d).

\section{Analytical Methods}

\subsection{Sample Preparation and Modal Analysis}

All the samples were washed with $\mathrm{H}_{2} \mathrm{O}_{2}$ to remove organic matter, dried and sieved from 8 to $0.062 \mathrm{~mm}$. Sieves with $1 \Phi$ intervals were used for samples from the riverbed (OFA-3b and OFA-13bis), while $\frac{1}{2} \Phi$ sieving intervals were used for the finer beach sands (OFA-22 and CA). The same procedure was followed for sample OFA-22b (concentration of dark minerals in the sands of Ofanto mouth). The different granulometric fractions were preliminary observed under the stereomicroscope in order to detect those containing the highest amount of volcanic minerals. Polished, uncovered, and thin sections for the petrographic and microanalytical study were prepared with a $0.25-0.50 \mathrm{~mm}(0.25-0.355$ for beach samples) size fraction of the samples. For the OFA-22 site, we used the bulk sample (OFA-22) for petrographic and modal analysis, the heavy mineral accumulation (OFA-22b) for microanalysis, and crystal separation for isotopic analysis.

A petrographic examination and modal analysis by the point-counting method was carried out on the four bulk samples under the optical polarizing microscope. At least three hundred points for each thin section were counted following the Gazzi-Dickinson method [32,33].

\subsection{Microanalysis}

Selected heavy volcanic minerals (pyroxene, amphibole and melanite garnet) were analyzed by Electron Probe Micro-Analyzer (EPMA) on polished, graphite-coated thin 
sections. We used the JEOL JXA-8230 instrument of the SILA-CM2 lab at the University of Calabria, equipped with 5 WDS spectrometers, with LiF, PETJ, TIAP and LiFL crystals and one EDS spectrometer. This instrument is also equipped with secondary electrons (SE), and back-scattered electrons (BSE) detectors as well as an optical microscope. WDS analyses were carried out with an accelerating voltage of $15 \mathrm{keV}$ and probe current of $10 \mathrm{nA}$. Count times were $15 \mathrm{~s}$ for $\mathrm{Na}$ and $30 \mathrm{~s}$ for other elements. The chrome diopside standard of SPI supplies (SPI\#02757-AB, serial 4AK) was used as a reference material and was analyzed twice before each analysis session with the same analytical conditions. Accuracy, calculated as the relative difference with respect to reference values, was always better than $1 \%$ for $\mathrm{SiO}_{2}, \mathrm{CaO}$ and $\mathrm{MgO}$ and $5 \%$ for the rest of major elements. An analysis of the standard and its certified values are presented in the Supplementary Material Table S1.

\subsection{Strontium and Neodymium Isotopic Composition Analysis}

From the same grain size fraction used for petrographic and microanalysis, pyroxene crystals were picked by hand for isotopic analyses. When occurring, different families of pyroxene, with either light or dark colors, were selected (Figure 3). Only for sample OFA-13bis was it possible to separate an amount of amphibole crystals sufficient for isotopic analyses. For each category, at least $0.2 \mathrm{~g}$ of material was separated and successively washed in an ultrasonic bath using deionized water.

Sample pre-treatment and dissolution, as well as Sr-Nd separation from the matrix, were carried out within a Plexiglas laminar flow hood equipped with two HEPA filters, located in an ISO 6 class clean room at Dipartimento di Scienze della Terra, dell'Ambiente e delle Risorse (DiSTAR, Naples, Italy). Before dissolution, an aliquot of separated and purified crystals sufficient for reaching the weight of $50 \mathrm{mg}$ (necessary weight to ensure that $\mathrm{Sr}$ and $\mathrm{Nd}$ are enough for statistically representative isotopic analyses), were leached with $6 \mathrm{~N}$ Suprapur ${ }^{\circledR}$ grade $\mathrm{HCl}$ for $10^{\prime}$ on a hot plate at ca. $80^{\circ} \mathrm{C}$, and then rinsed with Milli-Q ${ }^{\circledR}$ water (18.2 $\mathrm{M} \Omega$ resistivity) for $5^{\prime}$ on a hot plate; the procedure was repeated three times in order to get rid of possible secondary carbonates. Leached fractions were then dissolved with Suprapur ${ }^{\circledR}$ grade $\mathrm{HF}-\mathrm{HNO}_{3}-\mathrm{HCl}$ acid mixtures, the whole procedure lasting four days overall. $\mathrm{Sr}$ and $\mathrm{Nd}$ were separated from the matrix through conventional cation-exchange chromatographic techniques on quartz columns filled with either $\mathrm{AG}^{\circledR} 50 \mathrm{~W}-\mathrm{X} 8$ (for Sr and Rare Earth Elements) or Ln Spec ${ }^{\circledR}$ (for Nd) resins, using diluted Suprapur ${ }^{\circledR}$ grade $\mathrm{HCl}$ as eluent. The blank for Sr was $100 \mathrm{pg}$ during the period of chemistry processing, negligible considering the average Sr content of the studied pyroxenes, estimated to be $\sim 75$ ppm based on literature data [34]. In such a clean laboratory, no determination for $\mathrm{Nd}$ blank was believed to be necessary. The isotopic composition of $\mathrm{Sr}$ and $\mathrm{Nd}$ was determined at DiSTAR (Naples, Italy) through thermal ionization mass spectrometry (TIMS) techniques using a Thermo Scientific Triton Plus ${ }^{\circledR}$ mass spectrometer (Thermo Fisher Scientific, Bremen, Germany). The instrument was equipped with one fixed and eight adjustable Faraday cups for simultaneous acquisition of several ion beams in static mode. The standard error with $\mathrm{N}=150$, i.e., $2 \sigma$ mean, was better than \pm 0.000009 for both $\mathrm{Sr}$ and $\mathrm{Nd}$ measurements (Table 1). In-run isotopic fractionation was corrected through the normalization of measured ${ }^{87} \mathrm{Sr} /{ }^{86} \mathrm{Sr}$ and ${ }^{143} \mathrm{Nd} /{ }^{144} \mathrm{Nd}$ ratios to ${ }^{88} \mathrm{Sr} /{ }^{86} \mathrm{Sr}=8.37521$ and ${ }^{146} \mathrm{Nd} /{ }^{144} \mathrm{Nd}=0.7219$, respectively. During the period of analysis, replicate measurements of NIST-SRM $987\left(\mathrm{SrCO}_{3}\right)$ and JNdi-1 international reference standards were carried out to check for external reproducibility, $2 \sigma$ ( $\sigma$ is the standard deviation of the standard results, [35]), obtaining the following mean values: ${ }^{87} \mathrm{Sr} /{ }^{86} \mathrm{Sr}=0.710234 \pm 0.000013(\mathrm{~N}=48)$ for NIST-SRM 987; ${ }^{143} \mathrm{Nd} /{ }^{144} \mathrm{Nd}=0.512095 \pm 0.000006(\mathrm{~N}=31)$ for JNdi-1. The measured $\mathrm{Sr}$ and $\mathrm{Nd}$ isotope ratios were normalized to the recommended values of NIST-SRM 987 $\left({ }^{87} \mathrm{Sr} /{ }^{86} \mathrm{Sr}=0.710248 \pm 0.000012(\sigma),[36]\right)$ and $\mathrm{JNdi}-1\left({ }^{143} \mathrm{Nd} /{ }^{144} \mathrm{Nd}=0.512107 \pm 0.000012\right.$ $(\sigma)[36])$ standards, respectively. 

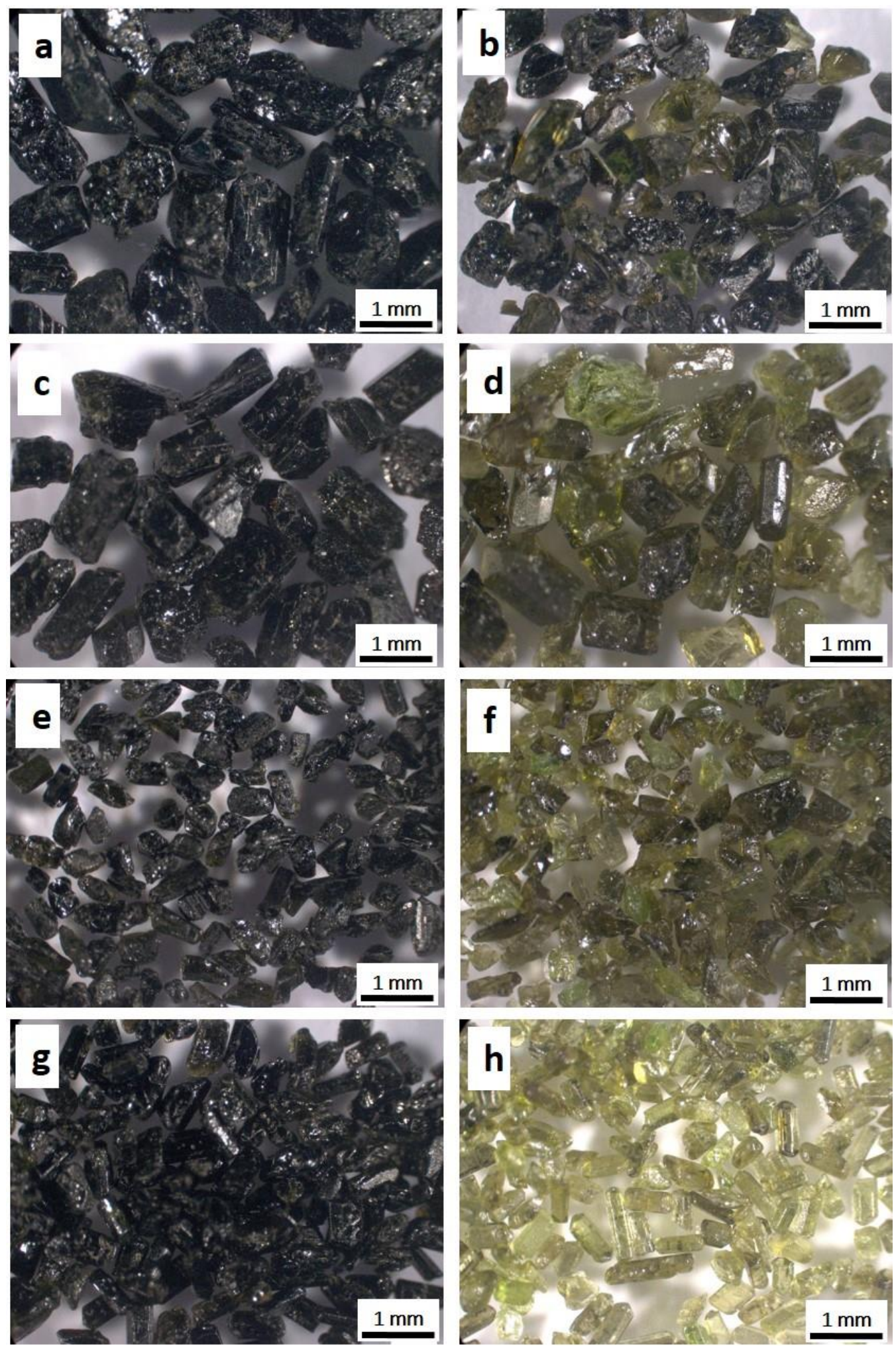

Figure 3. Separated clinopyroxene crystals selected for the isotopic analyses. (a,b): dark- and lightgreen crystals separated from the granulometric fraction between 0.25 and $0.50 \mathrm{~mm}$ of sample OFA-3b; $(\mathbf{c}, \mathbf{d})$ : dark- and light-green crystals separated from the granulometric fraction between 0.25 and $0.50 \mathrm{~mm}$ of sample OFA-13bis; $(\mathbf{e}, \mathbf{f})$ : dark- and light-green crystals separated from the granulometric fraction between 0.25 and $0.355 \mathrm{~mm}$ of sample OFA- $3 \mathrm{~b} ;(\mathbf{g}, \mathbf{h})$ : dark- and light-green crystals separated from the granulometric fraction between 0.25 and $0.355 \mathrm{~mm}$ of sample CA. 
Table 1. Sr- and Nd-isotope date.

\begin{tabular}{cccccc}
\hline Sample & Mineral & ${ }^{\mathbf{8 7}} \mathbf{S r} /{ }^{86} \mathbf{S r}$ & $\mathbf{2 s}$ & ${ }^{\mathbf{1 4 3}} \mathbf{N d} / \mathbf{1 4 4}^{\mathbf{N d}}$ & $\mathbf{2 s}$ \\
\hline \multirow{2}{*}{ OFA-3b } & green pyroxene & 0.708192 & \pm 0.000006 & 0.512463 & \pm 0.000005 \\
& dark pyroxene & 0.707208 & \pm 0.000007 & 0.512515 & \pm 0.000004 \\
OFA-13bis & green pyroxene & 0.705979 & \pm 0.000007 & 0.512687 & \pm 0.000005 \\
& dark pyroxene & 0.705774 & \pm 0.000007 & 0.512704 & \pm 0.000005 \\
OFA-22b & amphibole & 0.706053 & \pm 0.000008 & 0.512692 & \pm 0.000006 \\
& green pyroxene & 0.706170 & \pm 0.000006 & 0.512685 & \pm 0.000005 \\
CA & dark pyroxene & 0.705837 & \pm 0.000006 & 0.512693 & \pm 0.000005 \\
& green pyroxene & 0.707122 & $\pm 0.000006 *$ & 0.512493 & \pm 0.000008 \\
& dark pyroxene & 0.707483 & \pm 0.000006 & 0.512492 & \pm 0.000004 \\
\hline
\end{tabular}

(1) Data normalized against NIST SRM 987 (recommended ${ }^{87} \mathrm{Sr} /{ }^{86} \mathrm{Sr}=0.710248$; [36]); (2) data normalized against JNdi-1 (recommended $\left.{ }^{143} \mathrm{Nd} /{ }^{144} \mathrm{Nd}=0.512107 ;[36]\right) ;{ }^{*}$ weighted mean of two measurements.

\section{Results}

\subsection{Petrography and Modal Composition of the Sands}

In Figure 4, some photomicrographs on thin sections show the petrographic features of the analyzed sand samples. In Table 2 and Figure 5, the modal compositions of the analyzed samples are shown. Heavy-phases loose crystals are an important component of all the analyzed samples. They are represented by light-colored-to-green clinopyroxene and less abundant amphibole and garnet. The latter always has a light-to-dark-brown color, which allows us to identify it as melanite, a common accessory mineral in the alkaline volcanic rocks of Monte Vulture and Vesuvius [18,37]. Quartz commonly occurs in all the samples in coarse-grained sedimentary or metamorphic rock fragments or as a single grain. Additionally, in the latter case, however, it has been considered non-volcanic in origin, because it is not present as a mineral phase in the rocks of Southern Italy volcanoes. Feldspars are represented by orthoclase and minor microcline, while plagioclase is rare. Micas are always subordinate. Siliciclastic, carbonate, metamorphic and volcanic rock fragments with different textures occur in variable amounts in the four samples. In the sand fraction of the sample picked up in the upstream sector (OFA-3b), all the grains have rather sharp edges (Figure 4a). The most abundant components are represented by quartz and clinopyroxene single crystals, followed by feldspar (mainly represented by orthoclase and microcline and subordinately by plagioclase) (Figure 5a). Clinopyroxene ranges from colorless to green, sometimes with obvious zoning (Figure 4b). Minor amounts of lightbrown melanite garnet, amphibole and micas as single crystals also occur. Rock fragments also occur and include clasts of volcanic origin, mainly with microlithic or lathwork texture, carbonate clasts, siliciclastic sedimentary fragments and metamorphic rocks.

Sample OFA-13bis shows higher contents of heavy minerals of volcanic origin: clinopyroxene reaches $46 \%$, while amphibole and yellow-to-dark-brown melanite garnet represent 5 and $2 \%$, respectively (Figure $5 b$ ). Clinopyroxene often contains opaque minerals and occurs as light and more abundant dark-green crystals. It is not rare to find zoned crystals with a green core and lighter-colored rim or vice versa. They are sometimes surrounded by a rim of volcanic glass (Figure 4c). All the volcanic minerals have rather sharp edges, with only a few slightly rounded melanite crystals (Figure 4d). Volcanic rock fragments also contain a significant proportion of sand (12\%). They are generally sub-rounded and have microlithic and lathwork textures, with groundmass and microphenocrysts usually made of acicular plagioclase. The other components (quartz, microcline and orthoclase single crystals, rounded carbonate grains, siliciclastic and metamorphic rock fragments) are subordinate. 

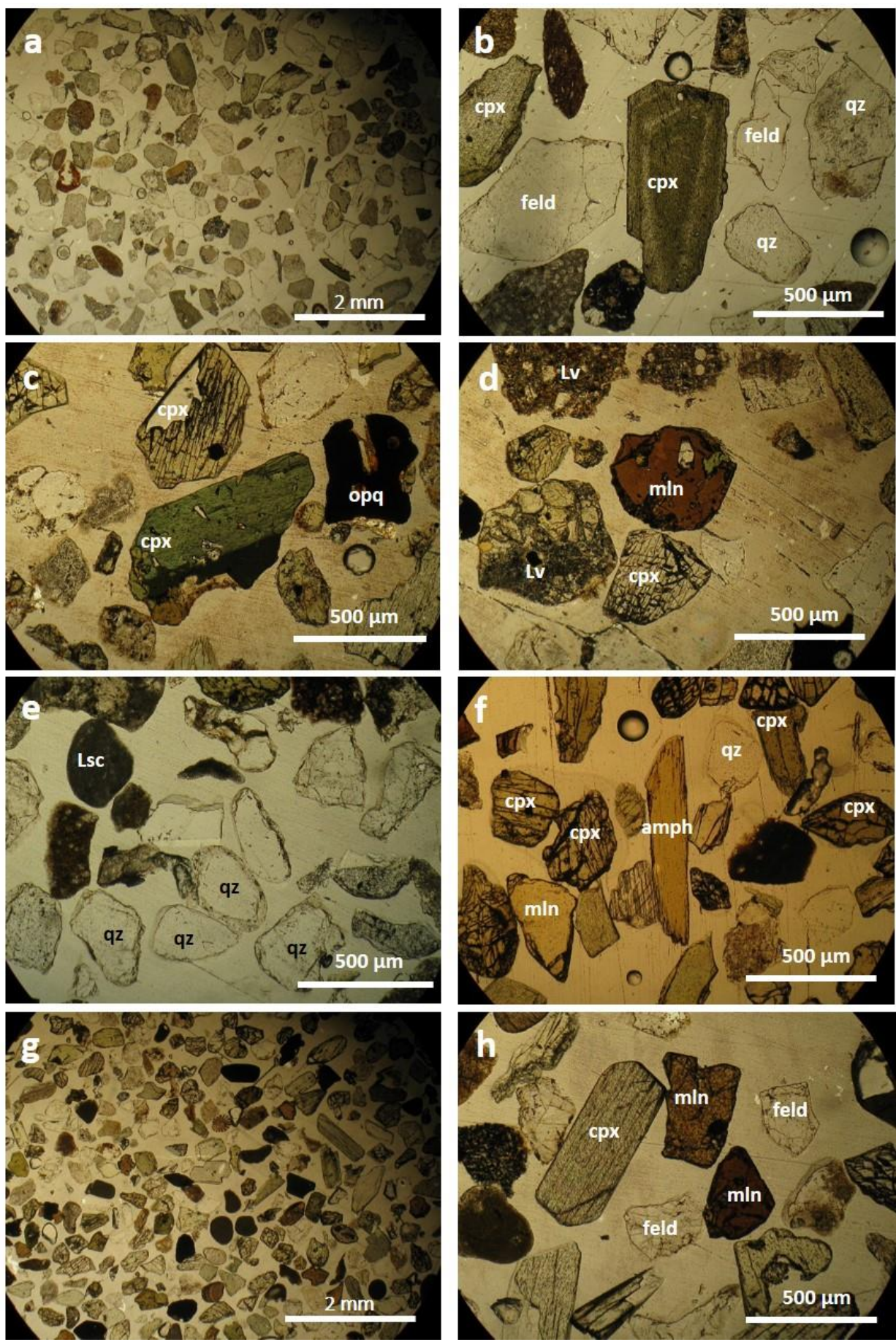

Figure 4. Microphotos of diagnostic grains in the studied samples. All the images are in planepolarized light. (a): sample OFA-3b, general view of the sand. Garnet (dark brown), light and dark-green pyroxene, quartz, feldspar and volcaniclastic rock fragments are visible. (b): sample OFA-3b, zoned, dark-green clinopyroxene (cpx), surrounded by quartz (qz) and feldspar (feld) crystals. A lightgreen pyroxene is also visible on the left; (c): sample OFA-13bis. Dark-green pyroxene surrounded by dark volcanic glass and light green pyroxene. An opaque (opq) is also visible on the right; (d): sample OFA-13bis, sub-rounded melanite ( $\mathrm{mln}$ ) crystal; (e): sample OFA-22, rounded quartz crystals and carbonatic sedimentary rock fragments (Lsc); (f): sample OFA-22, amphibole (amph), melanite and pyroxene crystals; (g): sample CA, general view of the sand. Light and dark green pyroxene, melanite, quartz and feldspar crystals and well-rounded carbonatic rock fragments are visible; (h): sample CA, melanite, pyroxene and feldspar crystals. 
Table 2. Modal composition of the sands.

\begin{tabular}{ccccc}
\hline Sample & OFA-3b & $\begin{array}{c}\text { OFA-13 } \\
\text { bis }\end{array}$ & OFA-22 & CA \\
\hline Lm & 5.3 & 1.7 & 3.7 & 11.8 \\
Lss & 4.7 & 5.0 & 4.3 & 0.0 \\
Lsc & 7.3 & 3.7 & 24.7 & 18.0 \\
Lv & 9.0 & 12.3 & 0.0 & 0.0 \\
Q & 27.0 & 7.7 & 25.7 & 15.6 \\
F & 13.3 & 8.3 & 11.7 & 9.6 \\
Opq & 0.0 & 0.0 & 0.7 & 2.4 \\
Px & 27.3 & 45.3 & 25.7 & 23.6 \\
Amph & 0.3 & 5.3 & 1.7 & 7.8 \\
Mlt & 0.7 & 2.0 & 1.0 & 5.4 \\
M & 0.7 & 1.7 & 0.3 & 0.0 \\
ind./alt. & 4.3 & 5.7 & 0.7 & 6.0 \\
Px+Amph+Mlt+Lv & 37.3 & 65.0 & 28.3 & 36.7 \\
\hline Abbreviations as in Figure 5 & & & &
\end{tabular}
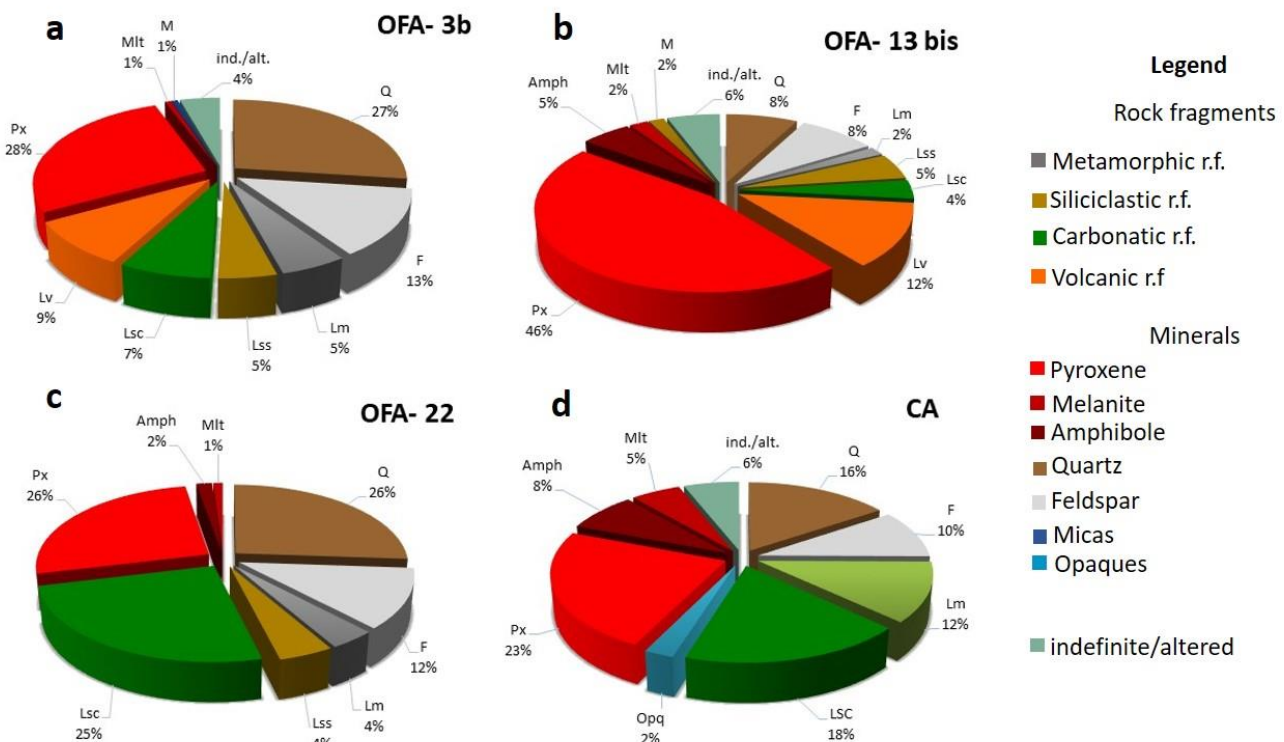

Figure 5. Modal composition of the sands of the studied samples. $(\mathbf{a}-\mathbf{c})$ : samples collected along the course of the Ofanto River, modified after [8]; (d): sample CA collected from the Cilento Beach.

In the beach sample picked up at the mouth of the Ofanto River (OFA-22) a high percentage of carbonate rock fragments occur, due to the erosion of the Bradanic foredeep sediments [8]. Single, mainly rounded quartz crystals are also abundant (Figure 4e). The volcaniclastic fraction is represented exclusively by loose clinopyroxene crystals $(26 \%)$ and minor amphibole and melanite (Figure $4 \mathrm{f}$ ), while volcanic rock fragments are absent (Figure 5c).

Finally, in the beach sand of Castellabate, well-rounded carbonate rock fragments prevail on the other sedimentary and metamorphic rock components (Figures $4 \mathrm{~g}$ and $5 \mathrm{~d}$ ). A significant volcaniclastic fraction occurs, exclusively represented by loose crystals of colorless-to-green pyroxenes, amphibole and yellow-to-brown melanite garnet (Figure $4 \mathrm{~h}$ ). Volcanic rock fragments are very rare and display a microlithic texture.

\subsection{Heavy Volcanic Minerals Composition}

EMPA-WDS average analyses of clinopyroxene, garnet and amphibole are listed in Table 3. The whole set of data is provided in the (Supplementary Material Tables S2-S4, respectively). 
Table 3. Average composition of the volcanic heavy minerals obtained by EPMA.

\begin{tabular}{|c|c|c|c|c|c|c|c|c|c|c|c|c|c|c|}
\hline \multicolumn{5}{|c|}{ Clinopyroxene } & \multicolumn{5}{|c|}{ Melanite } & \multicolumn{5}{|c|}{ Amphibole } \\
\hline Sample & $\begin{array}{c}\text { OFA 3b } \\
(30)\end{array}$ & $\begin{array}{c}\text { OFA-13bis } \\
\text { (35) }\end{array}$ & $\begin{array}{c}\text { OFA-22b } \\
\text { (7) }\end{array}$ & $\begin{array}{l}\text { CA } \\
(23)\end{array}$ & Sample & $\begin{array}{c}\text { OFA-3b } \\
\text { (11) }\end{array}$ & $\begin{array}{l}\text { OFA-13bis } \\
\text { (9) }\end{array}$ & $\begin{array}{c}\text { OFA-22b } \\
\text { (7) }\end{array}$ & $\begin{array}{l}\text { CA } \\
\text { (11) }\end{array}$ & Sample & $\begin{array}{c}\text { OFA-3b } \\
\text { (5) }\end{array}$ & $\begin{array}{c}\text { OFA-13bis } \\
\text { (2) }\end{array}$ & $\begin{array}{l}\text { OFA-22b } \\
\text { (3) }\end{array}$ & $\begin{array}{l}\text { CA } \\
\text { (3) }\end{array}$ \\
\hline $\mathrm{SiO}_{2}$ & 45.07 & 46.49 & 46.64 & 43.90 & $\mathrm{SiO}_{2}$ & 34.65 & 34.30 & 34.00 & 35.66 & $\mathrm{SiO}_{2}$ & 36.29 & 39.21 & 37.61 & 37.92 \\
\hline $\mathrm{TiO}_{2}$ & 1.29 & 1.37 & 1.20 & 1.62 & $\mathrm{TiO}_{2}$ & 3.46 & 5.53 & 3.84 & 3.16 & $\mathrm{TiO}_{2}$ & 2.19 & 2.20 & 1.89 & 1.92 \\
\hline $\mathrm{Al}_{2} \mathrm{O}_{3}$ & 8.21 & 7.90 & 6.64 & 8.75 & $\mathrm{Al}_{2} \mathrm{O}_{3}$ & 8.09 & 5.52 & 6.31 & 8.64 & $\mathrm{Al}_{2} \mathrm{O}_{3}$ & 15.27 & 16.31 & 13.93 & 13.58 \\
\hline $\mathrm{Cr}_{2} \mathrm{O}_{3}$ & 0.07 & 0.01 & 0.03 & 0.01 & $\mathrm{Cr}_{2} \mathrm{O}_{3}$ & 0.01 & 0.02 & 0.01 & 0.03 & $\mathrm{Cr}_{2} \mathrm{O}_{3}$ & 0.02 & 0.02 & 0.02 & 0.01 \\
\hline $\mathrm{Fe}_{2} \mathrm{O}_{3}$ & 6.46 & 3.31 & 3.94 & 3.05 & $\mathrm{Fe}_{2} \mathrm{O}_{3}$ & 15.22 & 16.60 & 16.69 & 13.79 & $\mathrm{Fe}_{2} \mathrm{O}_{3}$ & 4.36 & 6.72 & 4.51 & 1.97 \\
\hline $\mathrm{FeO}$ & 5.95 & 7.09 & 5.45 & 9.82 & $\mathrm{FeO}$ & 5.33 & 4.96 & 3.83 & 4.56 & $\mathrm{FeO}$ & 16.52 & 5.73 & 11.80 & 15.75 \\
\hline $\mathrm{MnO}$ & 0.00 & 0.28 & 0.26 & 0.31 & $\mathrm{MnO}$ & 1.02 & 0.62 & 0.91 & 1.14 & $\mathrm{MnO}$ & 0.00 & 0.15 & 0.38 & 0.96 \\
\hline $\mathrm{NiO}$ & 0.01 & 0.02 & 0.02 & 0.03 & MgO & 0.28 & 0.65 & 0.43 & 0.37 & MgO & 6.79 & 12.51 & 9.33 & 7.42 \\
\hline MgO & 9.50 & 10.31 & 11.45 & 8.46 & $\mathrm{CaO}$ & 31.53 & 30.90 & 32.14 & 31.34 & $\mathrm{CaO}$ & 11.14 & 11.58 & 11.20 & 10.72 \\
\hline $\mathrm{CaO}$ & 23.09 & 21.97 & 22.53 & 22.10 & & & & & & $\mathrm{Na}_{2} \mathrm{O}$ & 1.77 & 1.73 & 1.45 & 1.74 \\
\hline $\mathrm{Na}_{2} \mathrm{O}$ & 0.55 & 0.56 & 0.38 & 0.00 & & & & & & $\mathrm{~K}_{2} \mathrm{O}$ & 2.74 & 1.83 & 2.30 & 2.71 \\
\hline $\mathrm{K}_{2} \mathrm{O}$ & 0.01 & 0.08 & 0.02 & 0.13 & & & & & & & & & & \\
\hline sum & 100.22 & 99.38 & 98.55 & 98.18 & sum & 99.59 & 99.11 & 98.16 & 98.69 & sum & 97.10 & 97.99 & 94.43 & 94.70 \\
\hline $\mathrm{Si}$ & 1.71 & 1.76 & 1.77 & 1.71 & $\mathrm{Si}$ & 2.86 & 2.85 & 2.86 & 2.93 & Si & 5.67 & 5.74 & 5.89 & 6.01 \\
\hline Al & 0.29 & 0.24 & 0.23 & 0.29 & $\mathrm{Al}^{\mathrm{IV}}$ & 0.14 & 0.15 & 0.14 & 0.07 & $\mathrm{Al}^{\mathrm{IV}}$ & 2.33 & 2.26 & 2.11 & 1.99 \\
\hline Al & 0.07 & 0.11 & 0.07 & 0.11 & $\mathrm{Al}^{\mathrm{VI}}$ & 0.67 & 0.42 & 0.51 & 0.80 & $\mathrm{Al}^{\mathrm{VI}}$ & 0.48 & 0.56 & 0.47 & 0.56 \\
\hline $\mathrm{Fe}^{3+}$ & 0.19 & 0.10 & 0.11 & 0.09 & $\mathrm{Fe}^{3+}$ & 0.95 & 1.04 & 1.06 & 0.85 & $\mathbf{T i}$ & 0.26 & 0.24 & 0.22 & 0.23 \\
\hline Mg & 0.53 & 0.58 & 0.65 & 0.49 & $\mathrm{Fe}^{2+}$ & 0.37 & 0.35 & 0.27 & 0.31 & $\mathrm{Fe}^{2+}$ & 2.16 & 0.70 & 1.58 & 2.10 \\
\hline $\mathrm{Fe}^{2+}$ & 0.19 & 0.23 & 0.17 & 0.32 & Mn & 0.07 & 0.04 & 0.06 & 0.08 & Mn & 0.00 & 0.02 & 0.05 & 0.13 \\
\hline Mn & 0.00 & 0.01 & 0.01 & 0.01 & Mg & 0.03 & 0.08 & 0.05 & 0.05 & $\mathbf{M g}$ & 1.58 & 2.73 & 2.15 & 1.74 \\
\hline $\mathrm{Ca}$ & 0.94 & 0.89 & 0.92 & 0.92 & $\mathrm{Ca}$ & 2.79 & 2.76 & 2.89 & 2.76 & $\mathrm{Ca}$ & 1.86 & 1.82 & 1.88 & 1.82 \\
\hline $\mathrm{Na}$ & 0.04 & 0.04 & 0.03 & 0.00 & & & & & & $\mathbf{N a}$ & 0.54 & 0.49 & 0.44 & 0.53 \\
\hline \multirow[t]{2}{*}{$\mathbf{K}$} & 0.00 & 0.00 & 0.00 & 0.01 & Total & 8.09 & 8.03 & 8.09 & 8.06 & $\mathbf{K}$ & 0.55 & 0.34 & 0.46 & 0.55 \\
\hline & & & & & & & & & & Total & 15.95 & 15.65 & 15.78 & 15.91 \\
\hline Z & 2.00 & 2.00 & 2.00 & 2.00 & Alm & 0.00 & 0.00 & 0.00 & 0.00 & & & & & \\
\hline \multirow[t]{2}{*}{ X Y } & 2.00 & 2.00 & 2.00 & 2.00 & Ti-Adr & 57.48 & 66.02 & 64.60 & 53.23 & & & & & \\
\hline & & & & & Grs & 38.62 & 28.67 & 30.86 & 42.03 & & & & & \\
\hline En & 28.62 & 32.14 & 34.67 & 26.75 & Prp & 1.27 & 3.41 & 2.05 & 1.69 & & & & & \\
\hline $\mathrm{Fe}$ & 20.57 & 18.35 & 15.98 & 22.93 & Sps & 2.61 & 1.83 & 2.44 & 2.96 & & & & & \\
\hline Wo & 50.81 & 49.51 & 49.35 & 50.32 & Uv & 0.03 & 0.07 & 0.05 & 0.09 & & & & & \\
\hline
\end{tabular}

Numbers in brackets refer to the number of analyzed points. 
The color difference observed under the optical microscope for the clinopyroxene of the four samples is a consequence of compositional differences, ranging from diopside $\left(\mathrm{En}_{48} \mathrm{Fe}_{5}\right.$, $\mathrm{Mg \#}=0.9)$ to Fe-rich, hedenbergite terms $\left(\mathrm{En}_{15} \mathrm{Fe}_{35}, \mathrm{Mg \#}=0.3\right)$. All of the analyzed minerals are Ca-rich, with many crystals lying above the $\mathrm{CaMg}-\mathrm{CaFe}^{2+}$ node $\left(\mathrm{Wo}_{44}-53\right)$ (Figure 6a). Despite the high intra-sample compositional variability, no significant difference can be observed in terms of the major elements between the four analyzed samples.
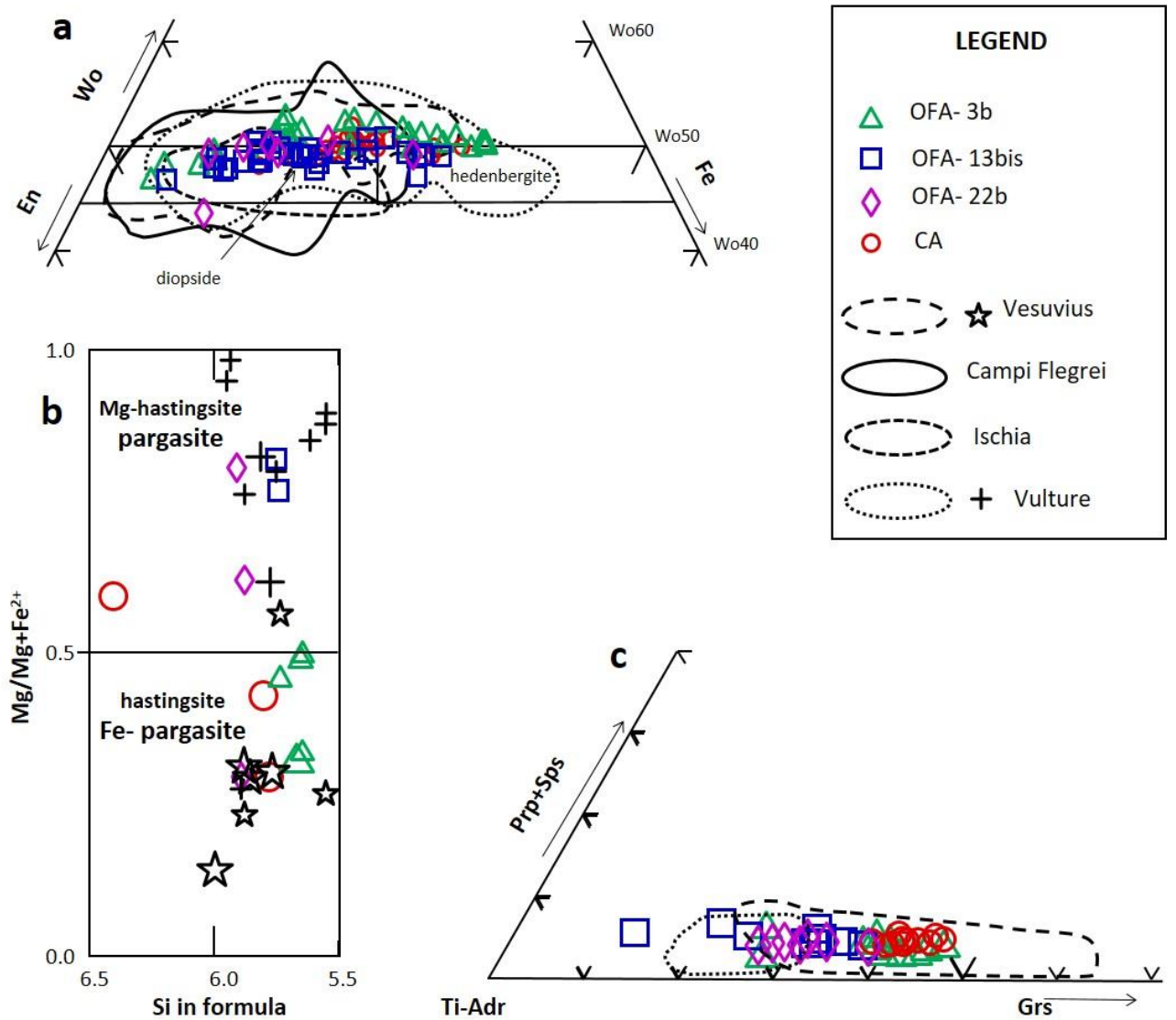

Figure 6. Composition of volcanic heavy minerals in the Ofanto River and Cilento sands. (a): Pyroxene composition. Compositional fields of clinopyroxene from Vulture (data from [18-20,39-41]), Vesuvius (data selected from [37,42]), Ischia (data from [43]) and Campi Flegrei (data from [44-53]) are shown for comparison; (b) amphibole (after [38]). Data of amphiboles from Vulture (from [18,20,40]) and Vesuvius (from [42]) are also shown for comparison. Smaller symbols indicate crystals with $\mathrm{Al}^{\mathrm{VI}}<\mathrm{Fe}^{3+}$ (Mg-hastingsite and hastingsite), bigger symbols indicate crystals with $\mathrm{Al}^{\mathrm{VI}}<\mathrm{Fe}^{3+}$ (pargasite and Fe-pargasite); (c) garnet. Compositional fields of garnet from Vulture (data from [18,20,54]) and Vesuvius (data from $[42,55,56]$ ) are also shown for comparison.

The few analyzed amphibole crystals have $\mathrm{Ca} \geq 1.5,(\mathrm{Na}+\mathrm{K}) \geq 0.50$ and $\mathrm{Ti}<0.50$. According to the classification of [38], crystals from the Ofanto upstream sector and Castellabate beach sand generally have $\mathrm{Mg} /\left(\mathrm{Mg}+\mathrm{Fe}^{2+}\right)$ lower than 0.5 and mostly fall in the hastingsite $\left(\mathrm{Al}^{\mathrm{VI}}<\mathrm{Fe}^{3+}\right)$ or Fe-pargasite $\left(\mathrm{Al}^{\mathrm{VI}}>\mathrm{Fe}^{3+}\right)$ fields, while those from the Ofanto central sector and mouth are mainly $\mathrm{Mg}$-hastingsite $\left(\mathrm{Mg} /\left(\mathrm{Mg}+\mathrm{Fe}^{2+}\right)>0.5\right.$ and $\left.\mathrm{Al}^{\mathrm{VI}}<\mathrm{Fe}^{3+}\right)$ (Figure 6b).

Garnet crystals have $\mathrm{CaO}$ contents higher than $30 \mathrm{wt} \%$ and total iron $>17 \mathrm{wt} \%$. Ti content is highly variable, ranging from 2.4 to $10.5 \mathrm{wt} \%$. Due to their peculiar composition, they can be classified as Ti-andradite or melanite garnets (Figure 6c), thus confirming the volcanic origin of this phase. Though a significant overlapping between the composition of garnets of the different samples exists, as an average, a difference between the crystals from different sectors of the Ofanto Basin can be appreciated, with garnets from the upstream 
sector showing compositions more shifted toward the grossular end-member with respect to those of the central sector and mouth. Garnets from Castellabate sand overlap with those of sample OFA-3b.

\subsection{Sr-Nd Isotopic Composition of Pyroxenes}

The Sr and $\mathrm{Nd}$ isotopic ratios of the analyzed samples are listed in Table 1. A strong heterogeneity can be observed between the pyroxenes of the sands sampled along the Ofanto River's course. Pyroxenes from the upstream sands display relatively high $\mathrm{Sr}$ (ca. 0.707-0.708) and low $\mathrm{Nd}(0.5124-0.5125)$ isotopic ratios. A slight difference can be observed in terms of isotopic ratios between the light- and dark-green pyroxene in this sample, with the latter showing higher $\mathrm{Nd}$ and lower Sr ratios.

Pyroxenes from the central part of the river and the mouth have a less radiogenic composition $\left({ }^{87} \mathrm{Sr} /{ }^{86} \mathrm{Sr}\right.$ ca. $0.706 ;{ }^{143} \mathrm{Nd} /{ }^{144} \mathrm{Nd}$ ca. 0.5127). However, the two samples are isotopically very similar. The differences between light- and dark-green pyroxenes are negligible; amphiboles of sample OFA-13b have the same isotopic composition of the pyroxenes of the same sample.

Finally, the Cilento Beach sand sample shows a relatively radiogenic isotopic composition of pyroxenes $\left({ }^{87} \mathrm{Sr} /{ }^{86} \mathrm{Sr}\right.$ ca. $0.707 ;{ }^{143} \mathrm{Nd} /{ }^{144} \mathrm{Nd}$ ca. 0.5125$)$, comparable with the dark green crystals of sample OFA-3b.

\section{Discussion}

\subsection{Multi-Source Origin of the Volcaniclastic Fraction}

The sands of the Ofanto River always contain a component of volcanic origin, represented by volcanic rock fragments, clinopyroxene, amphibole and melanitic garnet crystals [8]. Pyroxene crystals occur in the sandstones of the Sicilide Complex. However, their composition is subalkaline $(\mathrm{Ca}+\mathrm{Na}<1)$ and falls in the diopside and augite fields [57]. Therefore, the origin of the Ofanto sands' pyroxene from the erosion of this complex's sandstones can be ruled out. On the other hand, the occurrence of volcanic rock fragments and minerals in the sands of the central and final sectors of the river can be reasonably explained by the erosion of Monte Vulture volcanics. In particular, sampling site OFA-13 (Figure 1) is fed almost exclusively from Monte Vulture volcanics (Figure 2b). Similarly, in the upstream area (sampling site OFA-3), the volcanic grains could be derived from the erosion of terraced volcaniclastic sediments formed during the building of the Monte Vulture volcano in the Pleistocene [8]. Alternatively, it could also be related to the direct decrease in highly fragmented pyroclastic material during the most violent explosive eruptions of Monte Vulture. However, the proximity of many other volcanoes in the Southern Mediterranean area, aside from Monte Vulture, makes the Ofanto Basin an area of the potential accumulation and drainage of volcanic material from different sources (Figure 1). In particular, the volcanoes of the Campanian province, including Vesuvius, Campi Flegrei, Ischia and Procida, are all situated at a distance lower than $100 \mathrm{~km}$ from sampling site OFA $3 b$ and, except for Procida, these are places of highly explosive eruptions, whose products are dispersed in the entire Mediterranean area (e.g., [5] and references therein).

Compositional and isotopic data clearly show that some differences occur between the volcanic minerals of the upstream sands, chemically and isotopically similar to those of the Cilento coast, and those of the central sector and mouth of the river. To clarify the origin of the volcaniclastic fraction in the Ofanto sand, in the diagrams of Figure 6, we compared the composition of heavy minerals with that of the same phases in the products of the Monte Vulture and Campanian volcanoes. Clinopyroxene is a ubiquitous phase in the products of all these volcanic centers, and its composition in terms of major elements hardly allows for identifying the volcanic source (Figure 6a). On the contrary, amphibole and garnet only occur in the products of some Monte Vulture and Vesuvius eruptions. The amphibole composition is rather variable, but that from Monte Vulture can be mainly classified as Mghastingsite, while Fe-pargasite is more common in the products from Vesuvius (Figure 6b). The composition of garnet is melanite in both cases, but the composition of that from 
Vesuvius is, on average, more shifted towards the grossular end-member with respect to Monte Vulture melanites, richer in the Ti-andradite terms (Figure 6c). For amphibole and garnet a significant compositional similarity can be appreciated between the crystals of the central sector and mouth of the Ofanto River, as well as Monte Vulture volcanics, while crystals of the upstream sector and those from the Cilento Beach overlap with the Vesuvius compositions.

$\mathrm{Sr}$ and Nd isotopic compositions offer a more robust tool to discriminate between Monte Vulture and Campanian volcanoes. In Figure 7, the isotopic compositions of Ofanto and Castellabate clinopyroxenes are compared with the Monte Vulture, Vesuvius, Campi Flegrei, Ischia and Procida whole-rock compositions. When available, pyroxene compositions from the same centers were also plotted. Vesuvius and Campi Flegrei have ${ }^{87} \mathrm{Sr} /{ }^{86} \mathrm{Sr}$ higher than 0.7065 and ${ }^{143} \mathrm{Nd} /{ }^{144} \mathrm{Nd}$ generally lower than 0.5126 , matching the values obtained for the pyroxenes of the upstream sector of the Ofanto River. As expected, the minerals of the Cilento Beach, fed by the volcaniclastic deposits of Campanian volcanoes, also show comparable values (Figure $7 \mathrm{a}, \mathrm{b}$ ). Ischia whole-rock and pyroxene isotopic compositions are slightly less radiogenic, with ${ }^{87} \mathrm{Sr} /{ }^{86} \mathrm{Sr}$ ranging between 0.705 and 0.708 and ${ }^{143} \mathrm{Nd} /{ }^{144} \mathrm{Nd}$ between 0.5125 and 0.5127 . These compositions only partially match those of the Ofanto sands and Cilento Beach (Figure 7c). Analogously, the few available data for Procida whole-rock compositions do not support an origin of the Ofanto and Cilento minerals by this volcanic center; after all, the low explosivity of the Procida eruptions precludes a dispersion of its products far away from the volcanic centers. Monte Vulture rocks have the least radiogenic compositions among the volcanoes here taken into account, with ${ }^{143} \mathrm{Nd} /{ }^{144} \mathrm{Nd}$ higher than 0.51255 and ${ }^{87} \mathrm{Sr} /{ }^{86} \mathrm{Sr}$ lower than 0.707 (Figure 7d). Their composition perfectly matches that of the pyroxenes of the central sector and the mouth of the Ofanto River.

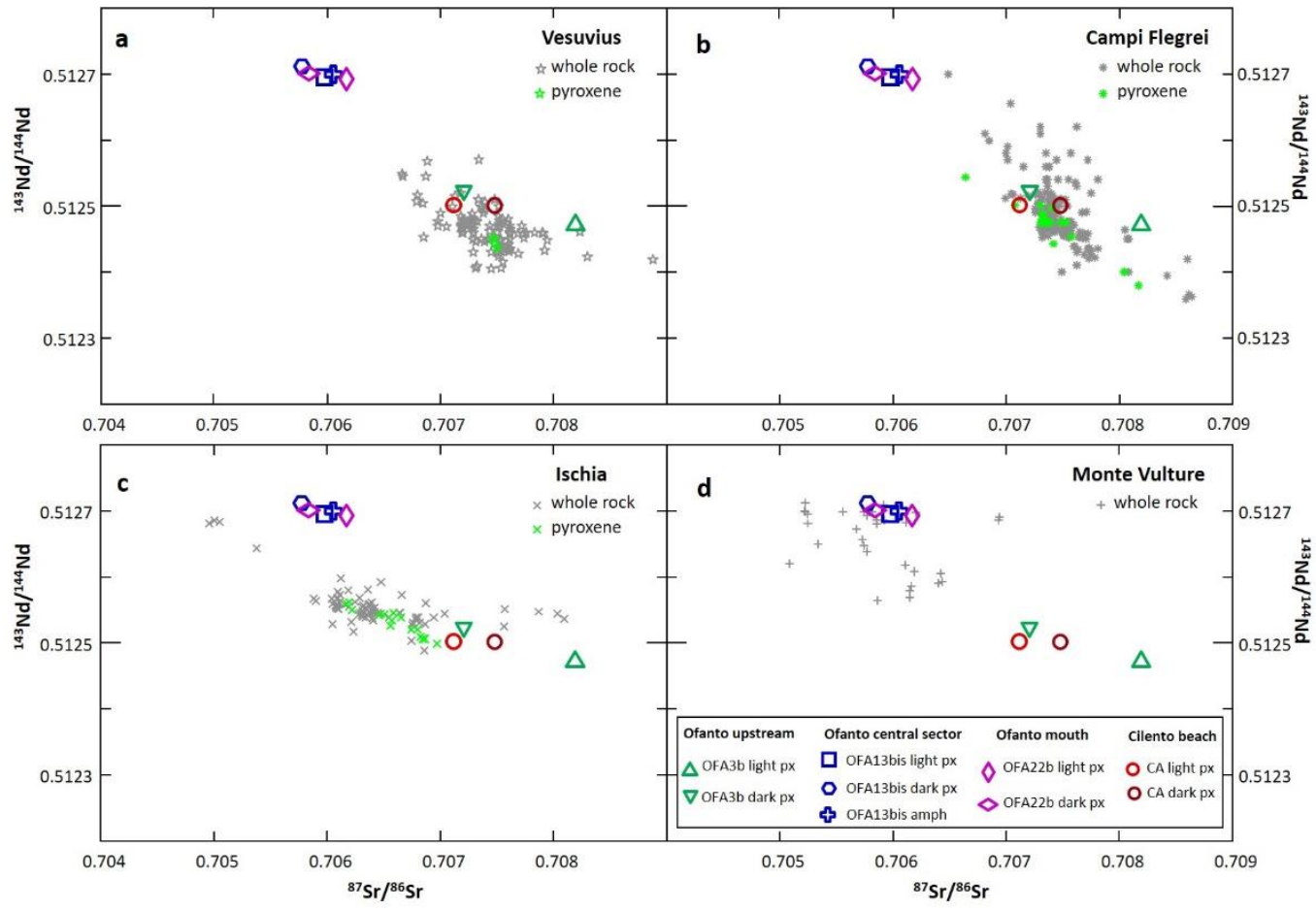

Figure 7. Nd-Sr isotopic composition of the pyroxenes of the studied samples compared to: (a) Vesuvius whole-rock and pyroxene (data from [58-64]); (b) Campi Flegrei whole-rock and pyroxene (data from $[46,53,65-73]$ ); (c) Ischia whole-rock and pyroxene (data from [51,61,65,67,74-78]); (d) Monte Vulture whole-rock (data from [75,79-82]).

On the whole, therefore, the compositional and isotopic data support an origin from Vesuvius and/or Campi Flegrei for the volcanic component in the upstream sector of the 
Ofanto River and an origin from Monte Vulture for the heavy minerals of the central sector and mouth of the river. The two components are well-recognizable and no mixing between them seems to occur in the analyzed samples.

\subsection{Identification of the Possible Eruption(s) Contributing to the Volcanic Component}

The mineral chemistry and the isotopic composition of pyroxene do not allow the specific eruptive event of either the Monte Vulture or Campanian volcanoes, which may have fed the river sands under study, to be identified. Moreover, it cannot be excluded that different eruptions, maybe also from different volcanoes, repeatedly dispersed their fall products in the Ofanto Basin and all contributed to the observed volcanic fraction in the river sands. However, some considerations can be made to try to identify the eruption(s) responsible for the high concentration of volcanic minerals in the upstream area on the basis of: (1) occurrence of garnet and amphibole, together with pyroxene, in the sands; (2) direction of dispersion of the volcanic plumes; (3) occurrence of volcaniclastic layers in the tephrostratigraphy of the Lago Grande di Monticchio or in the terraces of the Ofanto Basin.

Considering the Campanian volcanoes, melanite garnet occurs in the products of some Vesuvius eruptions only, while it does not occur in the products of Campi Flegrei or Ischia. In particular, its occurrence is limited to the eruptions of groups 2 (aged between 8 and $2.7 \mathrm{ka}$ ) and 3 (younger than $2.7 \mathrm{ka}$ ) (e.g., [37,83]), although ref [64] reports garnet in the Pomici di Base products (22 ka). Amphibole occurs in a few eruptions as well. In most cases, the products of Vesuvius were dispersed toward the E, ESE or ENE directions $[62,84]$. One of the few exceptions is represented by the eruption of Pompeii (79 AD), whose products were dispersed towards SSE [62]. Considering the simultaneous occurrence of garnet and amphibole and the dispersion of the eruptive columns, the three eruptions that most likely fed the volcanic components in the Ofanto Basin are:

- $\quad$ Pomici di Base eruption (22 ka), whose plinian phase produced $4.4 \mathrm{~km}^{3}$ of fall deposits, mainly dispersed toward ENE [62]. The petrography is dominated by sanidine, plagioclase, clinopyroxene and biotite and minor amounts of amphibole, magnetite and garnet [64].

- $\quad$ Pomici di Mercato eruption (ca. $8 \mathrm{ka}$ ), consisting of three plinian eruptions dispersed towards ENE [62]. The most abundant minerals are K-feldspar, clinopyroxene, plagioclase, garnet, amphibole and biotite, while apatite and Fe-Ti oxides are accessories [60]. - Avellino eruption (4.365 \pm 40 years, [62]), dispersed in the ENE direction. Sanidine is the most abundant phase, followed by clinopyroxene, amphibole, garnet, scapolite, nepheline and mica [62,84].

The younger eruptions of Pollena (472 AD and 1631 AD), though forming eruptive columns dispersed toward NE and E, respectively, contained garnet but not amphibole in the mineralogy of erupted products and can be discarded.

Tephra layers from all the eruptions mentioned above were detected, together with others from Campi Flegrei, the Aeolian Islands, Alban Hills and Etna, in cores in the Lago Grande di Monticchio sedimentary sequence, in the central sector of the Ofanto Basin $[23,85]$, and are thus likely contributors to the volcaniclastic fraction in the upstream sector of the Ofanto Basin. However, it cannot be excluded that part of the pyroxenes found in the Ofanto sands also derive from other explosive eruptions of Vesuvius, Campi Flegrei or Ischia. A contribution from the Campi Flegrei eruptions to the volcaniclastic sedimentation in the Ofanto Basin is also witnessed by the occurrence of two volcanic layers identified in the younger fluvial terraces of the Ofanto Basin. The first, which gave an ${ }^{40} \mathrm{Ar} /{ }^{39} \mathrm{Ar}$ age of $40.7 \pm 8.4 \mathrm{ka}$, was correlated with the Campanian Ignimbrite eruption. The second, dated to $25 \pm 5 \mathrm{ka}$, is likely related to an eruption of either Somma Vesuvius or Campi Flegrei [16,24,25], and could correspond to the Masseria del Monte Tuff $(29.3 \pm 0.7 \mathrm{ka}$, [86]). This suggests that Campi Flegrei eruptions are likely responsible for the occurrence of part of the volcanic fraction in the upstream sector. 


\subsection{Clues on the Fluvial Transport Process}

The results of the isotope data show that the sample picked up at the mouth of the Ofanto River has an isotopic composition perfectly overlapping with that of Monte Vulture. In contrast, the Campanian component was not detected. This could be explained by a "dilution" in the Campanian pyroxenes in the more abundant Monte Vulture crystals. The erosion of the volcanic edifice of Monte Vulture produces a large amount of volcaniclastic components in the sand of the Ofanto River. Moreover, lose or poorly cemented deposits related to erosion of Monte Vulture occur and are drained by the Ofanto River in the areas of Melfi and Atella in the Venosa basin to the northeast of the volcano and in the Middle-Pleistocene terraces to the north of the volcano [15,16,22,25,87-94]. Therefore, the accumulated Monte Vulture products can represent a source of volcanic minerals, even where the primary volcanic deposits are not drained. Though spatially limited, the lacustrine and fluvio-lacustrine deposits associated with Monte Vulture have a high rate of sand production and generate a great amount of volcanic minerals in the sand [8], contributing to increasing the volcanic fraction with a Monte Vulture signature in the deposits of the mouth. Therefore, it is possible, that, in the analyzed sample, the Campanian pyroxenes represent such a low percentage that their effect on the isotopic composition of the bulk sample is negligible.

An alternative explanation, however, could be that the sediment of the upstream sector does not reach the mouth of the river because it is trapped by artificial water regulation structures such as dams. A dam, especially of large capacity, can alter the flow regimes and trap entire sediment loads transported from upstream basins. For example, the sediment load in the Nile River in Egypt was reduced from approximately $100 \mathrm{Mt} / \mathrm{yr}$ to nearly zero because of the construction of the Aswan High Dam [95]. Likewise, the Three Gorges dam closure in 2003 led to a 95\% reduction in the sediment load of the Yangtze River in China, which decreased from $164 \mathrm{Mt} / \mathrm{yr}$ to $9 \mathrm{Mt} / \mathrm{yr}$ [96].

Since the 1950s, twenty dams have been built along the course of the Ofanto River [97]. As a consequence of these interventions, the Ofanto River has reduced its solid contribution from about $2 \times 10^{6}$ ton/year during the period 1935-1961 to about $0.6 \times 10^{6}$ ton/year in the period 1967-1976 and to about $0.2 \times 10^{6}$ in the following 20 years [98-100]. In particular, the Conza dam, a $46 \mathrm{~m}$ high zoned earth dam located in the upstream portion of the Ofanto River valley (see the position in Figure 1b) represents one of the largest reservoirs in the southern Apennine chain [101]. Therefore, the sediment of the upstream sector, including the Campania volcanic fraction, could be almost totally trapped by this structure. The dam could cause the absence of this volcanic component at the mouth of the Ofanto River. However, this hypothesis cannot be confirmed or disproved with the presented data. Future research in this direction could include a more detailed study of the isotopic composition of minerals picked up immediately downstream of the dam, in the active sediments of the riverbed and the terraces formed before the dam construction. This could give information on the capacity of the dam to confine the Campanian volcanic component in the upstream sector.

It is beyond the scope of this work to reconstruct the phases of fluvial transport, i.e., to understand the length and complexity of the history of erosion, sedimentation and the reworking of the volcanic minerals in the present sands of the Ofanto River. They could represent the erosion of primary pyroclastics or lavas from Monte Vulture, or of fall deposits from Campanian volcanoes. Alternatively, they could be multi-cyclic grains, deriving from the erosion of older terraces, such as those formed during the Pleistocene, when Monte Vulture was still active, or of other reworked deposits. The relatively sharp edges shown by most of the heavy mineral grains of the upstream and central sectors of the basin (Figure 4a-d) suggest a relatively short transport, and would point to an origin from the erosion of primary rocks. However, a detailed micro-morphoscopic study to determine the roundness and detect possible abrasion shapes of the grains will be necessary to obtain more detailed information on the fluvial transport process. 


\section{Conclusions}

The results of combined mineral chemistry and Sr-Nd isotopic characterization point to the identification of a double volcanic source that contributed to the heavy mineral fraction of the sands of the Ofanto River (Southern Italy). The mineral phases that proved to be the most diagnostic are clinopyroxene, amphibole and garnet. The Sr-Nd isotopic composition of clinopyroxene allowed for the precise identification of a provenance from Monte Vulture for sands of the central and final sectors of the river, and from the Campanian volcanoes for sands of the upstream area. For this river sector, located at less than $100 \mathrm{~km}$ from the Campanian volcanoes, the occurrence along with the clinopyroxene of amphibole and garnet suggested that Vesuvius was the most likely volcanic source. Pomici di Base (ca $22 \mathrm{ka}$ ), Pomici di Mercato (ca $8 \mathrm{ka}$ ) and Avellino (ca $4.4 \mathrm{ka}$ ) are the Vesuvius eruptions that most likely fed the volcaniclastic fractions of the upstream sector of the Ofanto River. Ischia and Procida can be ruled out based on both Sr-Nd isotopic features and the absence of amphibole and garnet phenocrysts. On the other hand, Campi Flegrei eruptions, such as Campanian Ignimbrite (ca $40 \mathrm{ka}$ ) and Masseria del Monte (ca $29 \mathrm{ka}$ ) may have contributed to part of the clinopyroxenes. Interestingly, mixed sands from the two main volcanic sources were detected in none of the three sampling sites.

The sands at the mouth of the Ofanto River perfectly match the isotopic composition of Monte Vulture products. The absence of a Campanian component might be explained by either a "dilution" effect by the more abundant Monte Vulture crystals, or the overall reduced sedimentary load of the river at the mouth due to trapping by dams built along the river.

Supplementary Materials: The following supporting information can be downloaded at https:// www.mdpi.com/article/10.3390/min12020232/s1, Table S1: analyzed EMPA Cr-diopside standard and certified values. Table S2: complete dataset of pyroxene EPMA microanalysis. Table S3: complete dataset of melanite garnet EPMA microanalysis. Table S4: complete dataset of amphibole EPMA microanalysis.

Author Contributions: Conceptualization, M.D., P.D. and R.D.R.; methodology, M.D. and P.D.; validation, R.S.I., F.T. and P.D.; formal analysis, R.S.I., F.T., M.D. and P.D.; investigation: picking and purification of mineral separates, R.S.I. and F.T.; sample dissolution and processing for Sr-Nd extraction, Sr-Nd isotopic analysis, R.S.I., F.T. and M.D.; EPMA microanalysis, P.D.; resources, M.D. and R.D.R.; data curation, P.D. and M.D.; writing—original draft preparation, P.D.; writing-review and editing, M.T., M.D. and R.D.R.; visualization, P.D. and M.T.; supervision, M.D. and P.D.; project administration, M.D. and P.D. funding acquisition, R.D.R. All authors have read and agreed to the published version of the manuscript.

Funding: This research received no external funding.

Data Availability Statement: All the new data obtained in this research are contained in the article or in the Supplementary Material.

Acknowledgments: We thank Rocco Dominici and Domenico Parise for their support in the field work and Mariano Davoli for help during EPMA analyses. We are grateful to Martina Coscarelli and Domenico Trapasso for helping during the laboratory work.

Conflicts of Interest: The authors declare no conflict of interest.

\section{References}

1. Peccerillo, A. Cenozoic Volcanism in the Tyrrhenian Region, 2nd ed.; Nemeth, K., Ed.; Springer: Berlin, Germany, 2017.

2. Peccerillo, A.; Lustrino, M. Compositional variations of Plio-Quaternary magmatism in the circum-Tyrrhenian area: Deep versus shallow mantle processes. Geol. Soc. Am. Spec. Pap. 2005, 388, 421. [CrossRef]

3. Bell, K.; Lavecchia, G.; Rosatelli, G. Cenozoic Italian magmatism-Isotope constraints for possible plume-related activity. J. South Am. Earth Sci. 2013, 41, 22-40. [CrossRef]

4. Giaccio, B.; Galli, P.; Peronace, E.; Arienzo, I.; Nomade, S.; Cavinato, G.P.; Mancini, M.; Messina, P.; Sottili, G. A 560-440 ka tephra record from the Mercure Basin, Southern Italy: Volcanological and tephrostratigraphic implications. J. Quat. Sci. 2014, 29, 232-248. [CrossRef] 
5. D'Antonio, M.; Mariconte, R.; Arienzo, I.; Mazzeo, F.C.; Carandente, A.; Perugini, D.; Petrelli, M.; Corselli, C.; Orsi, G.; Principato, M.S.; et al. Combined Sr-Nd isotopic and geochemical fingerprinting as a tool for identifying tephra layers: Application to deep-sea cores from Eastern Mediterranean Sea. Chem Geol 2016, 443, 121-136. [CrossRef]

6. Petrosino, P.; Arienzo, I.; Mazzeo, F.C.; Natale, J.; Petrelli, M.; Milia, A.; Perugini, D.; D'Antonio, M. The San Gregorio Magno lacustrine basin (Campania, Southern Italy): Improved characterization of the tephrostratigraphic markers based on trace elements and isotopic data. J. Quat Sci. 2019, 34, 393-404. [CrossRef]

7. De Bonis, A.; Arienzo, I.; D’Antonio, M.; Franciosi, L.; Germinario, C.; Grifa, C.; Guarino, V.; Langella, A.; Morra, V. Sr-Nd isotopic fingerprinting as a tool for ceramic provenance: Its application on raw materials, ceramic replicas and ancient pottery. J. Archaeol. Sci. 2018, 94. [CrossRef]

8. Tenuta, M.; Donato, P.; Dominici, R.; de Rosa, R. The influence of volcanic supply on the composition of modern river sands: The case study of the Ofanto river, Southern Italy. Geol. Soc. Lond. Spec. Pub. 2021, SP520-2021-89. [CrossRef]

9. Patacca, E.; Scandone, P. Geology of the Southern Apennines. Boll. Soc. Geol. It. 2007, SI 7, 75-119.

10. Vezzani, L.; Festa, A.; Ghisetti, F.C. Geology and tectonic evolution of the Central-Southern Apennines, Italy. Geol Soc. Am. Spec. Pap. 2010, 469. [CrossRef]

11. Giannandrea, P.; Marino, M.; Romeo, M.; Schiattarella, M. Pliocene to Quaternary evolution of the Ofanto Basin in Southern Italy: An approach based on the Unconformity-Bounded Stratigraphic Units. It. J. Geosci. 2014, 133, 27-44. [CrossRef]

12. Martelli, L.; Nardi, G.; Cammarosano, A.; Cavuoto, G.; Aiello, G.; D'Argenio, B.; Marsella, E. Note Illustrative della Carta Geologica d'Italia alla Scala 1: 50,000, Foglio 502 Agropoli; SystemCart: Rome, Italy, 2005.

13. Patacca, E.; Scandone, P. Il contributo degli studi stratigrafici di superficie e sottosuolo alla conoscenza dell'Appennino campanolucano. In Proceedings of the 1st Congresso dell'Ordine dei Geologi di Basilicata, "Ricerca, Sviluppo ed Utilizzo delle Fonti Fossili: Il Ruolo del Geologo", Potenza, Italy, 30 November-2 December 2012; pp. 97-153.

14. Critelli, S.; Le Pera, E. La formazione di Castelvetere nell'evoluzione petrostratigrafica dell'avanfossa del Tortoniano-Messiniano dell'Appennino meridionale. Boll. Soc. Geol. It. 1995, 114, 615-634.

15. Principe, C.; Giannandrea, P. UBSU e cartografia geologica: Problemi e potenzialità dell'utilizzo delle UBSU per l'interpretazione e la rappresentazione cartografica dei depositi quaternari vulcanici. L'esempio dei Fogli n.451 "Melfi" e n. 452 "Rionero in Vulture". Quaternario 2008, 21, 61-68.

16. Labella, R.; Capolongo, D.; Giannandrea, P.; Giano, S.I.; Schiattarella, M. Morphometric analysis of fluvial network and age constraints of terraced surfaces of the Ofanto Basin, southern Italy. Rend. Lincei. Sci. Fis. Nat. 2014, 25, 253-263. [CrossRef]

17. De Fino, M.; La Volpe, L.; Piccarreta, G. Magma evolution at Mount Vulture (southern Italy). Bull. Volcanol. 1982, 45, 115-126. [CrossRef]

18. Melluso, L.; Morra, V.; Di Girolamo, P. The Mt. Vulture volcanic complex (Italy): Evidence for distinct parental magmas and for residual melts with melilite. Mineral. Petrol. 1996, 56, 225-250. [CrossRef]

19. Bindi, L.; Cellai, D.; Melluso, L.; Conticelli, S.; Morra, V.; Menchetti, S. Crystal chemistry of clinopyroxene from alkaline undersaturated rocks of the Monte Vulture volcano, Italy. Lithos 1999, 46, 259-274. [CrossRef]

20. De Fino, M.; La Volpe, L.; Peccerillo, A.; Piccarreta, G.; Poli, G. Petrogenesis of Monte Vulture volcano (Italy): Inferences from mineral chemistry, major and trace element data. Contri. Mineral. Petrol. 1986, 92, 135-145. [CrossRef]

21. Stoppa, F.; Rosatelli, G.; Principe, C. Modal classification of Monte Vulture volcanics. In Geologia del Monte Vulture; Principe, C., Ed.; Grafiche Finiguerra: Lavello, Italy, 2006; pp. 87-105.

22. Schiattarella, M.; Giannandrea, P.; Principe, C.; La Volpe, L. Note Illustrative della Carta Geologica d'Italia Foglio 451 Melfi Scala 1:50,000; Litografia Artistica Cartografica: Firenze, Italy, 2016.

23. Wulf, S.; Kraml, M.; Brauer, A.; Keller, J.; Negendank, J.F.W. Tephrochronology of the 100ka Lacustrine Sediment Record of Lago Grande di Monticchio (southern Italy). Quat. Int. 2004, 122, 7-30. [CrossRef]

24. Buettner, A.; Principe, C.; Villa, I.M.; Bocchini, D. Geocronologia ${ }^{39}$ Ar- ${ }^{40}$ Ar del Monte Vulture. In La Geologia del Monte Vulture; Principe, C., Ed.; Grafiche Finiguerra: Lavello, Italy, 2006; pp. 73-86.

25. Giannandrea, P. I depositi terrazzati affioranti nell'alta valle del fiume Ofanto (Foglio n. 451 “"Melfi”', Appennino CampanoLucano). Quaternario 2004, 17, 511-521.

26. Martelli, L.; Nardi, G. Note Illustrative della Carta Geologica d'Italia Alla Scala 1:50,000, Foglio 503 Vallo della Lucania; SystemCart: Rome, Italy, 2005.

27. Bonardi, G.; Amore, F.O.; Ciampo, G.; De Capoa, P.; Miconnet, P.; Perrone, V. Il Complesso Liguride Auct.: Stato delle conoscenze e problemi aperti sulla sua evoluzione pre-Appenninca ed i suoi rapporti con 1'Arco Calabro. Mem. Soc. Geol. Ital. 1988, 41, 17-35.

28. Bonardi, G.; Di Nocera, S.; Sgrosso, I.; Brancaccio, L.; Cinque, A.; Morra, V.; Ortolani, F.; Torre, M.; Ciampo, G.; De Capoa, P. Carta geologica dell'Appennino meridionale 1:250.000. In Proceedings of the 74th Congresso della Società Geologica Italiana, Sorrento, Italy, 13 September 1988; Bonardi, G., D'Argenio, B., Perrone, V., Eds.; De Frede: Napoli, Italy, 1988.

29. Critelli, S. Petrologia delle areniti della formazione di San Mauro (Eocene Superiore-Oligocene Superiore, Bacino Del Cilento), Appennino meridionale. Mem. Soc. Geol. Ital. 1987, 38, 603-621.

30. Crisci, G.M.; Critelli, S.; De Rosa, R. Vulcanismo sinsedimentario nella successione terrigena della formazione di San Mauro (Miocene inferiore, Unità del Cilento), Appennino Meridionale. Mineral. Petrol. Acta 1988, 31, 159-178.

31. Morrone, C.; Le Pera, E.; Marsaglia, K.M.; De Rosa, R. Compositional and textural study of modern beach sands in the active volcanic area of the Campania region (Southern Italy). Sediment. Geol. 2020, 396, 105567. [CrossRef] 
32. Gazzi, P. Sulla determinazione microscopica della composizione mineralogica e granulometrica delle rocce, in particolare delle arenarie e delle sabbie. Mineral. Petrogr. Acta 1966, 12, 61-68.

33. Dickinson, W.R. Interpreting detrital modes of greywackes and arkoses. J. Sediment. Petrol. 1970, 40, 695-707.

34. Fedele, L.; Zanetti, A.; Morra, V.; Lustrino, M.; Melluso, L.; Vannucci, R. Clinopyroxene/liquid trace element partitioning in natural trachyte-trachyphonolite systems: Insights from Campi Flegrei (southern Italy). Contrib. Mineral. Petrol. 2009, 158, 337-356. [CrossRef]

35. Goldstein, S.L.; Deines, P.; Oelkers, E.H.; Rudnick, R.L.; Walter, L.M. Standards for publication of isotope ratio and chemical data in chemical geology. Chem. Geol. 2003, 202,1-4.

36. Zhang, W.; Hu, Z. Estimation of isotopic reference values for pure materials and geological reference materials. At. Spectrosc. 2020, 41, 93-102. [CrossRef]

37. Redi, D.; Cannatelli, C.; Esposito, R.; Lima, A.; Petrosino, P.; De Vivo, B. Somma-Vesuvius' activity: A mineral chemistry database. Mineral. Petrol. 2017, 111, 43-67. [CrossRef]

38. Leake, B.E.; Woolley, A.R.; Arps, C.E.S.; Birch, W.D.; Gilbert, M.C.; Grice, J.D.; Hawthorne, F.C.; Kato, A.; Kisch, H.J.; Krivovichev, V.G.; et al. Nomenclature of amphiboles: Report of the subcommittee on amphiboles of the International Mineralogical Association, commission on new minerals and mineral names. Canad. Mineral. 1997, 35, $219-246$.

39. Caggianelli, A.; De Fino, M.; La Volpe, L.; Piccarreta, G. Mineral chemistry of monte vulture volcanics: Petrological implications. Mineral. Petrol. 1990, 41, 215-227. [CrossRef]

40. Stoppa, F.; Principe, C. Eruption style and petrology of a new carbonatitic suite from the Mt. Vulture (southern Italy): The Monticchio Lakes Formation. J. Volcanol. Geoth Res. 1998, 80, 251-265. [CrossRef]

41. Solovova, I.P.; Girnis, A.V.; Kogarko, L.N.; Kononkova, N.N.; Stoppa, F.; Rosatelli, G. Compositions of magmas and carbonatesilicate liquid immiscibility in the Vulture alkaline igneous complex, Italy. Lithos 2005, 85, 113-128. [CrossRef]

42. Joron, J.L.; Metrich, N.; Rosi, M.; Santacroce, R.; Sbrana, A. Chemistry and petrography. In Somma Vesuvius; Santacroce, R., Ed.; CNR Quaderni della Ricerca Scientifica: Rome, Italy, 1987; Volume 114, pp. 105-174.

43. D'Antonio, M.; Arienzo, I.; Brown, R.J.; Petrosino, P.; Pelullo, C.; Giaccio, B. Petrography and mineral chemistry of Monte Epomeo Green Tuff, Ischia island, south Italy: Constraints for identification of the Y-7 tephrostratigraphic marker in distal sequences of the central Mediterranean. Minerals 2021, 11, 955. [CrossRef]

44. Orsi, G.; Civetta, L.; D’Antonio, M.; Di Girolamo, P.; Piochi, M. Step-filling and development of a three-layer magma chamber: The Neapolitan Yellow Tuff case history. J. Volcanol. Geoth. Res. 1995, 67, 291-312. [CrossRef]

45. Fourmentraux, C.; Métrich, N.; Bertagnini, A.; Rosi, M. Crystal fractionation, magma step ascent, and syn-eruptive mingling: The Averno 2 eruption (Phlegraean Fields, Italy). Contrib. Mineral. Petrol. 2012, 163, 1121-1137. [CrossRef]

46. Arienzo, I.; Mazzeo, F.C.; Moretti, R.; Cavallo, A.; D’Antonio, M. Open-system magma evolution and fluid transfer at Campi Flegrei caldera (southern Italy) during the past $5 \mathrm{ka}$ as revealed by geochemical and isotopic data: The example of the Nisida eruption. Chem. Geol. 2016, 427, 109-124. [CrossRef]

47. Mollo, S.; Forni, F.; Bachmann, O.; Blundy, J.D.; De Astis, G.; Scarlato, P. Trace element partitioning between clinopyroxene and trachy-phonolitic melts: A case study from the Campanian Ignimbrite (Campi Flegrei, Italy). Lithos 2016, 252, 160-172. [CrossRef]

48. Forni, F.; Bachmann, O.; Mollo, S.; De Astis, G.; Gelman, S.E.; Ellis, B.S. The origin of a zoned ignimbrite: Insights into the Campanian Ignimbrite magma chamber (Campi Flegrei, Italy). Earth Planet. Sci. Lett. 2016, 449, 259-271. [CrossRef]

49. Fedele, L.; Scarpati, C.; Sparice, D.; Perrotta, A.; Laiena, F. A Chemostratigraphic study of the Campanian Ignimbrite eruption (Campi Flegrei, Italy): Insights on magma chamber withdrawal and deposit accumulation as revealed by compositionally zoned stratigraphic and facies framework. J. Volcanol. Geoth. Res. 2016, 324, 105-117. [CrossRef]

50. Belkin, H.E.; Rolandi, G.; Jackson, J.C.; Cannatelli, C.; Doherty, A.L.; Petrosino, P.; De Vivo, B. Mineralogy and geochemistry of the older (>40 ka) ignimbrites on the Campanian plain, southern Italy. J. Volcanol. Geoth. Res. 2016, 323, 1-18. [CrossRef]

51. Iovine, R.S.; Fedele, L.; Mazzeo, F.C.; Arienzo, I.; Cavallo, A.; Wörner, G.; Orsi, G.; Civetta, L.; D’Antonio, M. Timescales of magmatic processes prior to the $\sim 4.7$ ka Agnano-Monte Spina eruption (Campi Flegrei Caldera, Southern Italy) based on diffusion chronometry from sanidine phenocrysts. Bull. Volcanol. 2017, 79, 1-15. [CrossRef]

52. Astbury, R.L.; Petrelli, M.; Ubide, T.; Stock, M.J.; Arienzo, I.; D’Antonio, M.; Perugini, D. Tracking plumbing system dynamics at the Campi Flegrei caldera, Italy: High-resolution trace element mapping of the Astroni crystal cargo. Lithos 2018, 318, 464-467. [CrossRef]

53. Di Salvo, S.; Avanzinelli, R.; Isaia, R.; Zanetti, A.; Druitt, T.; Francalanci, L. Crystal-mush reactivation by magma recharge: Evidence from the Campanian Ignimbrite activity, Campi Flegrei volcanic field, Italy. Lithos 2020, 376, 105780. [CrossRef]

54. Scordari, F.; Schingarod, E.; Pedrazzi, G. Crystal Chemistry of Melanites from Mt. Vulture (Southern Italy). Eur. J. Mineral. 1999, 11, 855-869. [CrossRef]

55. Scheibner, B.; Heumann, A.; Wörner, G.; Civetta, L. Crustal residence times of explosive phonolite magmas: U-Th ages of magmatic ca-garnets of Mt. Somma-Vesuvius (Italy). Earth Planet. Sci. Lett. 2008, 276, 293-301. [CrossRef]

56. Wotzlaw, J.F.; Guillong, M.; Balashova, A.; Forni, F.; Dunkl, I.; Mattsson, H.B.; Bachmann, O. In-situ garnet ${ }^{238}{ }^{2}{ }^{230}$ Th geochronology of Holocene silica-undersaturated volcanic tuffs at millennial-scale precision. Quat. Geochronol. 2019, 50, 1-7. [CrossRef]

57. Fornelli, A.; Piccarreta, G. Mineral and chemical provenance indicators in some Early Miocene sandstones of the Southern Apennines (Italy). Eur. J. Mineral. 1997, 9, 433-448. [CrossRef] 
58. Gasperini, D.; Blichert-Toft, J.; Bosch, D.; Del Moro, A.; Macera, P.; Albarède, F. Upwelling of deep mantle material through a plate window: Evidence from the geochemistry of Italian basaltic volcanics. J. Geophys Res. Solid Earth 2002, 107, ECV 7-1-ECV 7-19. [CrossRef]

59. Di Renzo, V.; Di Vito, M.A.; Arienzo, I.; Carandente, A.; Civetta, L.; D’Antonio, M.; Giordano, F.; Orsi, G.; Tonarini, S. Magmatic history of Somma-Vesuvius on the basis of new geochemical and isotopic data from a deep borehole (Camaldoli della Torre). J. Petrol. 2007, 48, 753-784. [CrossRef]

60. Aulinas, M.; Civetta, L.; Di Vito, M.A.; Orsi, G.; Gimeno, D.; Férnandez-Turiel, J.L. The “Pomici di Mercato" plinian eruption of Somma-Vesuvius: Magma chamber processes and eruption dynamics. Bull. Volcanol. 2008, 70, 825-840. [CrossRef]

61. Avanzinelli, R.; Elliott, T.; Tommasini, S.; Conticelli, S. Constraints on the genesis of potassium-rich Italian volcanic rocks from U/Th disequilibrium. J. Petrol. 2008, 49, 195-223. [CrossRef]

62. Santacroce, R.; Cioni, R.; Marianelli, P.; Sbrana, A.; Sulpizio, R.; Zanchetta, G.; Donahue, D.J.; Joron, J.L. Age and whole rock-glass compositions of proximal pyroclastics from the major explosive eruptions of Somma-Vesuvius: A review as a tool for distal tephrostratigraphy. J. Volcanol. Geoth Res. 2008, 177, 1-18. [CrossRef]

63. Pappalardo, L.; Buono, G.; Fanara, S.; Petrosino, P. Combining textural and geochemical investigations to explore the dynamics of magma ascent during plinian eruptions: A Somma-Vesuvius volcano (Italy) case study. Contrib. Mineral. Petrol. 2018, 173, 1-20. [CrossRef]

64. Buono, G.; Pappalardo, L.; Harris, C.; Edwards, B.R.; Petrosino, P. Magmatic stoping during the caldera-forming Pomici di Base eruption (Somma-Vesuvius, Italy) as a fuel of eruption explosivity. Lithos 2020, 370, 105628. [CrossRef]

65. D'Antonio, M.; Tonarini, S.; Arienzo, I.; Civetta, L.; Di Renzo, V. Components and processes in the magma genesis of the Phlegrean volcanic district, Southern Italy. Geol Soc. Am. Spec. Pap. 2007, 418, 203-220. [CrossRef]

66. Tonarini, S.; D’Antonio, M.; Di Vito, M.A.; Orsi, G.; Carandente, A. Geochemical and B-Sr-Nd isotopic evidence for mingling and mixing processes in the magmatic system that fed the Astroni volcano (4.1-3.8 ka) within the Campi Flegrei caldera (Southern Italy). Lithos 2009, 107, 135-151. [CrossRef]

67. Tonarini, S.; Leeman, W.P.; Civetta, L.; D'Antonio, M.; Ferrara, G.; Necco, A. B/Nb and $\delta^{11}$ B systematics in the Phlegrean volcanic district, Italy. J. Volcanol. Geoth. Res. 2004, 133, 123-139. [CrossRef]

68. Di Renzo, V.; Arienzo, I.; Civetta, L.; D'Antonio, M.; Tonarini, S.; Di Vito, M.A.; Orsi, G. The magmatic feeding system of the Campi Flegrei caldera: Architecture and temporal evolution. Chem. Geol. 2011, 281, 227-241. [CrossRef]

69. Pabst, S.; Wörner, G.; Civetta, L.; Tesoro, R. magma chamber evolution prior to the Campanian Ignimbrite and Neapolitan Yellow Tuff eruptions (Campi Flegrei, Italy). Bull. Volcanol. 2008, 70, 961-976. [CrossRef]

70. Arienzo, I.; Civetta, L.; Heumann, A.; Wörner, G.; Orsi, G. Isotopic evidence for open system processes within the Campanian Ignimbrite (Campi Flegrei-Italy) magma chamber. Bull. Volcanol. 2009, 71, 285-300. [CrossRef]

71. Di Vito, M.A.; Arienzo, I.; Braia, G.; Civetta, L.; D’Antonio, M.; Di Renzo, V.; Orsi, G. The Averno 2 fissure eruption: A recent small-size explosive event at the Campi Flegrei caldera (Italy). Bull. Volcanol. 2011, 73, 295-320. [CrossRef]

72. Arienzo, I.; D’Antonio, M.; Di Renzo, V.; Tonarini, S.; Minolfi, G.; Orsi, G.; Carandente, A.; Belviso, P.; Civetta, L. Isotopic microanalysis sheds light on the magmatic endmembers feeding volcanic eruptions: The Astroni 6 case study (Campi Flegrei, Italy). J. Volcanol. Geoth. Res. 2015, 304, 24-37. [CrossRef]

73. Pappalardo, L.; Piochi, M.; D'Antonio, M.; Civetta, L.; Petrini, R. Evidence for multi-stage magmatic evolution during the past $60 \mathrm{kyr}$ at Campi Flegrei (Italy) deducted from $\mathrm{Sr}, \mathrm{Nd}$ and Pb isotope data. J. Petrol. 2002, 43, 1415-1434. [CrossRef]

74. Slejko, F.F.; Petrini, R.; Orsi, G.; Piochi, M.; Forte, C. Water speciation and Sr isotopic exchange during water-melt interaction: A combined NMR-TIMS study on the Cretaio Tephra (Ischia Island, South Italy). J. Volcanol. Geoth. Res. 2004, 133, 311-320. [CrossRef]

75. D'Antonio, M.; Tonarini, S.; Arienzo, I.; Civetta, L.; Dallai, L.; Moretti, R.; Orsi, G.; Andria, M.; Trecalli, A. Mantle and crustal processes in the magmatism of the Campania region: Inferences from mineralogy, geochemistry, and Sr-Nd-O isotopes of young hybrid volcanics of the Ischia Island (South Italy). Contrib. Mineral. Petrol. 2013, 165, 1173-1194. [CrossRef]

76. Casalini, M.; Avanzinelli, R.; Heumann, A.; De Vita, S.; Sansivero, F.; Conticelli, S.; Tommasini, S. Geochemical and radiogenic isotope probes of Ischia volcano, Southern Italy: Constraints on magma chamber dynamics and residence time. Am. Mineral. 2017, 102, 262-274. [CrossRef]

77. Brown, R.J.; Civetta, L.; Arienzo, I.; D'Antonio, M.; Moretti, R.; Orsi, G.; Tomlinson, E.L.; Albert, P.G.; Menzies, M.A. Geochemical and isotopic insights into the assembly, evolution and disruption of a magmatic plumbing system before and after a cataclysmic caldera-collapse eruption at Ischia Volcano (Italy). Contrib. Mineral. Petrol. 2014, 168, 1-23. [CrossRef]

78. Pelullo, C.; Cirillo, G.; Iovine, R.S.; Arienzo, I.; Aulinas, M.; Pappalardo, L.; Petrosino, P.; Fernandez-Turiel, J.L.; D’Antonio, M. Geochemical and $\mathrm{Sr}-\mathrm{Nd}$ isotopic features of the Zaro Volcanic Complex: Insights on the magmatic processes triggering a small-scale prehistoric eruption at Ischia Island (South Italy). Int. J. Earth Sci. 2020, 109, 2829-2849. [CrossRef]

79. De Astis, G.; Kempton, P.D.; Peccerillo, A.; Wu, T.W. Trace element and isotopic variations from Mt. Vulture to Campanian volcanoes: Constraints for slab detachment and mantle inflow beneath Southern Italy. Contrib. Mineral. Petrol. 2006, 151, 331-351. [CrossRef]

80. D'Orazio, M.; Innocenti, F.; Tonarini, S.; Doglioni, C. Carbonatites in a subduction system: The Pleistocene alvikites from Mt. Vulture (Southern Italy). Lithos 2007, 98, 313-334. [CrossRef] 
81. Conticelli, S.; Carlson, R.W.; Widom, E.; Serri, G. Chemical and isotopic composition (Os, Pb, Nd, and Sr) of Neogene to Quaternary calc-alkalic, shoshonitic, and ultrapotassic mafic rocks from the Italian peninsula: Inferences on the nature of their mantle sources. Geol. Soc. Am. Spec. Pap. 2007, 418, 171-202. [CrossRef]

82. Koornneef, J.M.; Nikogosian, I.; van Bergen, M.J.; Smeets, R.; Bouman, C.; Davies, G.R. TIMS analysis of Sr and Nd isotopes in melt inclusions from Italian potassium-rich lavas using prototype $10^{13} \Omega$ amplifiers. Chem. Geol. 2015, 397, 14-23. [CrossRef]

83. Paone, A. The geochemical evolution of the Mt. Somma-Vesuvius volcano. Mineral. Petrol. 2006, 87, 53-80. [CrossRef]

84. Sulpizio, R.; Bonasia, R.; Dellino, P.; Mele, D.; Di Vito, M.A.; La Volpe, L. The Pomici di Avellino eruption of Somma-Vesuvius (3.9 Ka BP). Part II: Sedimentology and physical volcanology of pyroclastic density current deposits. Bull. Volcanol. 2010, 72, 559-577. [CrossRef]

85. Wulf, S.; Keller, J.; Paterne, M.; Mingram, J.; Lauterbach, S.; Opitz, S.; Sottili, G.; Giaccio, B.; Albert, P.G.; Satow, C.; et al. The 100-133 ka record of Italian explosive volcanism and revised tephrochronology of Lago Grande di Monticchio. Quat. Sci. Rev. 2012, 58, 104-123. [CrossRef]

86. Albert, P.G.; Giaccio, B.; Isaia, R.; Costa, A.; Niespolo, E.M.; Nomade, S.; Pereira, A.; Renne, P.R.; Hinchliffe, A.; Mark, D.F.; et al. Evidence for a large-magnitude eruption from Campi Flegrei caldera (Italy) at 29 ka. Geology 2019, 47, 595-599. [CrossRef]

87. La Volpe, L.; Rapisardi, L. Osservazioni geologiche sul versante meridionale del M. Vulture; genesi ed evoluzione del bacino lacustre di Atella. Boll. Soc. Geol. It. 1977, 96, 181-197.

88. Bonadonna, F.P.; Brocchini, D.; Laurenzi, M.A.; Principe, C.; Ferrara, G. Stratigraphical and chronological correlations between Monte Vulture volcanics and sedimentary deposits of the Venosa Basin. Quat. Int. 1998, 47-48, 87-96. [CrossRef]

89. Giannandrea, P.; La Volpe, L.; Principe, C.; Schiattarella, M. Unità stratigrafiche a limiti inconformi e storia evolutiva del vulcano medio-pleistocenico di Monte Vulture (Appennino meridionale, Italia). Boll. Soc. Geol. It. 2006, 125, 67.

90. Schiattarella, M.; Beneduce, P.; Di Leo, P.; Giano, S.I.; Giannandrea, P.; Principe, C. Assetto strutturale ed evoluzione morfotettonica quaternaria del vulcano del Monte Vulture (Appennino lucano). Boll. Soc. Geol. It. 2005, 124, 543-562.

91. Giannandrea, P. Evoluzione sedimentaria della successione alluvionale e lacustre quaternaria del Bacino di Venosa (Italia meridionale). Alp. Mediterr Quat 2009, 22, 269-290.

92. Giannandrea, P.; La Volpe, L.; Principe, C.; Schiattarella, M. Carta Geologica del Monte Vulture Alla Scala 1:25,000; Litografia Artistica Cartografica: Firenze, Italy, 2004.

93. Giannandrea, P. Il bacino fluvio-lacustre di Venosa. In La Geologia del Monte Vulture; Principe, C., Ed.; Grafiche Finiguerra: Lavello, Italy, 2006; pp. 55-72.

94. Giannandrea, P. Carta geologica del bacino di Venosa; Litografia Artistica Cartografica: Firenze, Italy, 2006.

95. Milliman, J.D.; Syvitski, J.P.M. Geomorphic/Tectonic Control of Sediment Discharge to the Ocean: The Importance of Small Mountainous Rivers. J. Geol. 1992, 100, 525-544. [CrossRef]

96. Tena, A.; Batalla, R.J. The sediment budget of a large river regulated by dams (the lower river Ebro, NE Spain). J. Soils Sediments 2013, 13, 966-980. [CrossRef]

97. Mastronuzzi, G.; Pye, K.; Sansò, P.; Sergio, A. The impact of dam construction and coast protection works on beach sediment budgets and erosional accretion trends: Examples from Apulia, Southern Italy, and Eastern and Southern England. In Proceedings of the Environmental Sedimentology IAS-SEPM, Meeting on Environmental Sedimentology, Venezia, Italy, 27 October 1997.

98. Caldara, M.; Centenaro, E.; Mastronuzzi, G.; Sansò, P.; Sergio, A. Features and present evolution of apulian coast (southern italy). J. Coast. Res. 1998, 26, 55-64.

99. Caldara, M. Aspetti di geologia ambientale e di morfologia costiera in alcuni tratti del litorale nord-barese. In Atti del Convegno "Cave e Coste nel Territorio Nord-Barese, Problematiche Ambientali" Suppl. 2/96 Geologi; Arti Grafiche Savarese: Bari, Italy, $1996 ;$ pp. 39-61.

100. Mastronuzzi, G.; Sansò, P.; Bruckner, H.; Voett, A.; Pignatelli, C.; Caputo, R.; Coppola, D.; Di Bucci, D.; Fracassi, U.; May, S.M.; et al. Palaeotsunami imprints along the coasts of the central Mediterranean Sea. In Proceedings of the Field Guide-2nd International Tsunami Field Symposium; Mastronuzzi; Mastronuzzi, G., Pignatelli, C., Sansò, P., Milella, M., Selleri, G., Eds.; Ostuni: Puglia, Italy; Ionian Islands, Greece, 2008.

101. Di Martire, D.; Iglesias, R.; Monells, D.; Centolanza, G.; Sica, S.; Ramondini, M.; Pagano, L.; Mallorquí, J.J.; Calcaterra, D. Comparison between differential SAR interferometry and ground measurements data in the displacement monitoring of the earth-dam of Conza della Campania (Italy). Remote Sens. Environ. 2014, 148, 58-69. [CrossRef] 